Digitized by the Internet Archive in 2008 with funding from Microsoft Corporation 




\section{DOGMA, FACT AND EXPERIENCE}




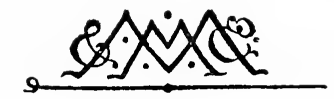

\author{
MACMILLAN AND CO., Limited \\ LONDON - BOMBAY - CALCUTTA \\ MELBOURNE
}

THE MACMILLAN COMPANY

NEW YORK - BOSTON - CHICAGO

DALLAS - SAN FRANCISCO

THE MACMILLAN CO. OF CANADA, ItT. TORONTO 


\title{
DOGMA, FACT AND
}

\section{EXPERIENCE}

BY

\author{
A. E. J. RAWLINSON \\ STUDENT OF CHRIST CHURCH \\ EXAMINING CHAPLAIN TO THE BISHOP OF LICHFIELD \\ FORMERLY TUTOR OF KEBLE COLLEGE, OXFORD
}

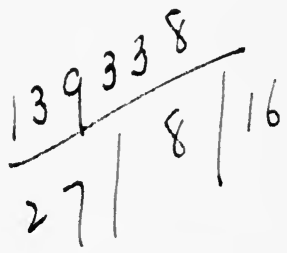

MACMILLAN AND CO., LIMITED ST. MARTIN'S STREET, LONDON 
COPYRIGHT 


\section{PREFACE}

OF the essays included in this little volume the first two are reprinted, with slight modifications, from the pages of the Interpreter and the Irish Church Quarterly respectively, and my thanks are due to the editors of those periodicals for permission to republish. The third essay I had originally written as a supplement to an enlarged edition of Foundations which was at one time in contemplation, though the project was subsequently abandoned. I have added papers dealing with our Lord's outlook upon the future and with the subject of "Clerical Veracity," because those topics are of immediate theological or ecclesiastical importance.

I am indebted to numerous friends for 


\section{vi DOGMA, FACT \& EXPERIENCE}

help and encouragement; and in particular to Dr. H. S. Holland and to Dr. G. A. Cooke, who each read one of the essays in MS.; to the Bishop of Bloemfontein and to Dr. A. E. Burn, who were kind enough to send me some notes; to the Rev. Wilfrid Richmond, for the opportunity of seeing his paper on "The Risen Body"; and to the Rev. D. C. Simpson, Tutor of Keble College, Oxford, who helped me by reading the proofs. The responsibility for what I have written is, of course, wholly my own.

A. E. J. R.

OxfoRd, July 1915. 


\section{CONTENTS}

I
Religion and Temperament
II

Dogma AND History . . . . . . $\quad$. 22

III

The Resurrection and the Life $\quad$ - $\quad 53$

\section{IV}

OUR Lord's View of the Future . . 112

V

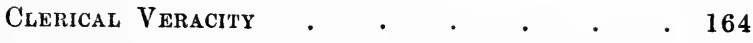




\section{DOGMA, FACT AND EXPERIENCE

RELIGION AND TEMPERAMENT

IT was remarked in the opening sentence of one of the papers read before the Pan-Anglican Conference a few years back that among the many interesting discoveries made by natural science in the course of the last century was that of the existence of religion. To-day we are familiar with a large and growing literature devoted to the study of religion and of religious experience, considered simply as psychological fact. The late Professor William James's well-known book, The Varieties of Religious Experience, is but typical of a multitude of similar works in which the attempt is made to describe and classify the 


\section{DOGMA, FACT \& EXPERIENCE}

various types of religious life and experience which are actually discoverable among mankind. The method employed does not necessarily involve any assumptions, whether of a positive or negative kind, as to the truth of the beliefs investigated, or the ultimate justification of the religious attitude towards the world. It is perfectly compatible with the most entire scepticism even as regards the fundamental dogma of the existence of God. The fact that men do, as a matter of fact, believe for the most part in a God or gods with whom they conceive themselves to hold communion can never of itself establish the proposition that they are right in so doing; and the actual beliefs and experiences of mankind may well be studied for their psychological interest even by those who regard them as illusory. This is a consideration which may well give pause to the too confident apologists who have looked to the new study to provide them with something like a "scientific" demonstration of religious truth.

Yet it is not to be denied that the psychological mode of approach, provided that its limitations are clearly recognized, may form a 
valuable starting-point of religious inquiry. The broad dilemma, either that religion-even (it may be) the Christian religion-is true, or that most of what is best and highest in human experience is grounded ultimately in illusion, undoubtedly possesses a certain cogency. For good or for evil, the psychological method and the historico-critical mode of approach to religious facts are at present dominant in the world of theology and religious thinking; and, like every habit of thought which prevails for the time being among the experts, it inevitably exercises an influence, powerful though unperceived, upon the mind of the plain man. It has come about, therefore, that religion to-day is very commonly regarded as a peculiar kind of "experience"-an "experience" which some men enjoy and others do not. It is this conception of "religious experience" which it is the purpose of the present essay to estimate and to criticize.

If we assume for the moment the truth of what is ordinarily meant by religion-that is to say, if we regard man as standing in relation (whether he recognizes the fact or not) to 


\section{DOGMA, FACT \& EXPERIENCE}

a Supreme Being who is not less than personal, who is his Maker, and to glorify whom is the end of his existence and his only ultimate good,- - then we might be disposed to say that the whole of human experience is, or ought to be, religious. This, surely, is the proper and correct use of terms; but it is not the sense in which the phrase "religious experience" is currently employed in modern speech and writing. For good or for evil, the significance of the words has been narrowed, so that men commonly speak of "religious experience" in the sense not of experience in general, considered as religious, but rather of experiences in particular-that is to say, states of consciousness of a certain more or less specific type.

"The first evidence to the religious man of the existence of God," writes Mr. Temple, "is his own religious experience. No one who has had even a moment of such experience can afterwards quite ignore it; it will perpetually challenge his attention." 1 Other writers speak of a "religious sense" or a "consciousness of God"-a kind of mystical

1 W. Temple, The Faith and Modern Thought, p. 4. 
assurance of communion with the Divine, experienced at particular times or in particular moods, and especially, no doubt, (though by no means exclusively), in prayer and meditation, or in sacramental worship and communion. It is an acknowledged fact that in the lives of many men such states of consciousness do, in fact, occur ; they may even, by such practices as those of prayer and worship and communion, be more or less successfully induced; they are, moreover, comforting, and result in a general sense of peace and wellbeing, and the memory of them may be a source of strength and support at other times, when the "experience" in question is no longer present.

No one, presumably, would wish to undervalue such experiences, or even to deny to them a certain evidential value. If they are not to be taken as illusory, they must imply both that God exists and that the spirit of man is capable of holding conscious intercourse with the Spirit of God. But it is surely a mistake to identify such emotional or quasimystical states with religion; and it is to be feared that the narrowed usage of the term 


\section{DOGMA, FACT \& EXPERIENCE}

"religious experience" at present in vogue is in danger of involving the popular mind in this confusion. Religion, in other words, is in peril of being identified with what is really one of its "separable accidents"-viz., the capacity for experiencing states of consciousness of the type which may be described as mystical or devout, and the habit of doing so.

The effects of such an identification of religion with "religious sense" are fatal. For in the first place such moods of devout emotion are intermittent and not continuous, even in the case of those who experience them frequently; while in the experience of most men they are even comparatively rare. If they are to be taken as essential to religion, it must follow that the majority of mankind are incapable of being more than intermittently religious. Religion, according to a current definition, is communion with God; and if communion with God is assumed necessarily to imply the realized sense of God's presence, then in the case of most men the maintenance of unbroken communion with God must be abandoned even as an ideal. Conversely, if-as is surely the case-unbroken communion with God is 
to be regarded as the ideal for all Christians, the existence of such communion must be held to be compatible with inability to realize it, except occasionally, in explicit consciousness.

In the second place, the popular equation of religion with sensible piety is apt to result in a self-centred preoccupation with one's own emotional states, which is in the highest degree unhealthy. The religious man who conceives his religion in this way is perpetually feeling his own spiritual pulse ; he becomes, as it were, a religious hypochondriac. Just as in the case of bodily health it is only when men are ill that they notice whether they are healthy or not, so may it not be an indication of spiritual disorder when a man begins to concern himself with the question whether he is or is not experiencing sensible devotion?

Thirdly-and this is perhaps the most serious consideration of all-it appears to be established as the result of the investigations of religious psychologists that the capacity for experiencing states of consciousness of the type commonly called "religious" is largely, if not wholly, a matter of temperament. Some men are devout or pious by temperament, and 


\section{DOGMA, FACT \& EXPERIENCE}

others are not. Is a clear recognition of this fact to be taken as carrying with it the conclusion that religion is a thing of which some men are constitutionally incapable? The Christian shrinks from such a conclusion; but it is nevertheless difficult to see how the inference is to be evaded by the type of apologetic which builds upon a "religious sense" supposed to be possessed by men in varying degrees and exhibited conspicuously by the few whom we call "saints," or which compares. religious faith to an ear for music or to an appreciation of art; there are so many individuals in whom such capacities are lacking. It is not surprising that those who begin by speaking of the "religious sense" frequently go on to speak of the "religious temperament," or that those who do not happen to be endowed by nature with a temperament of the kind suggested are led to infer that religion is not for them. Such a conclusion is perfectly consistent with an admiration for "religious people," amounting at times even to envy; it is a conclusion at which men frequently arrive with real regret; but the conclusion is none the less inevitably drawn, 


\section{RELIGION \& TEMPERAMENT 9}

and if the implied conception of religion is correct, it is difficult not to say that it is rightly drawn.

The argument, in short, can only be evaded by quarrelling, not with its conclusion, but with its premisses; by challenging root and branch the prevalent confusion of religion itself with a particular temperamental accompaniment of religion ; in other words, by drawing a clear distinction between religion on the one hand, and piety or devoutness of feeling on the other. This distinction is one which for some reason or other devout people apparently find it extremely difficult to draw; with St. Paul they are perpetually saying, in effect if not in words, "I would that all men were even as I myself"; and the result is that, as a religious teacher of our day has acutely if paradoxically remarked, "Religion in the modern world is in danger of being ikilled by pious people."

Now, the fundamental error which underlies the confusion of religion with piety is the direct result of the psychological mode of approach. Religion, considered purely psychologically, is quite inevitably thought of as 


\section{DOGMA, FACT \& EXPERIENCE}

centred in the religious man. If we are thinking of our fellows as religious, we think of religion as a characteristic of them: it is their religion, something which they happen to have. Similarly, if we are bold to think of ourselves as religious, we speak of our religion, as of something characteristic of $u s$, centred in ourselves. Yet the most superficial analysis of religion itself shows that it claims to be, and if it is to be considered more than illusory it must be, something far more than this.

Certainly it has ever been the claim of Christianity that it is centred not in man but in God; it is not a state of our consciousness, but a relation between ourselves and God, in which God does not depend upon us, but we upon Him. Logically, it is no doubt true that the existence of God may be viewed in the light of an inference from the data of religious experience; but when once that inference has been drawn and the assumption made that it is true, then we must turn round and say that God is ontologically the prior term in the relation; that $\mathrm{He}$ knows us, whether we know Him or not; that He claims 


\section{RELIGION \& TEMPERAMENT 11}

us, whether we realize His claim or not; that our being depends upon and derives from His, whether or not we are sensible of His presence or conscious of our communion with Him. If God has made us unto Himself and claims us, then it may well be that $\mathrm{He}$ claims from us something more than that we should experience emotions; and since we cannot in fact experience the latter to order, and moreover are not responsible for our temperaments, may it not be that He claims from us something for which we are responsible, and which we can continue to render even though sensible devotion be suspended or lacking?

At this point we may consider the supreme example of religion in the Person of our Lord. As Christians we believe that $\mathrm{He}$, who is the expression in terms of manhood of the character and life of God, reveals also by the same act (because man is made in God's image and likeness) the ideal life for man. Of what nature, then, was the religious life of Jesus of Nazareth ? We are tempted, no doubt, to assume that our Lord's consciousness of communion with His Heavenly Father endured for the most part unbroken and continuous; 
12 DOGMA, FACT \& EXPERIENCE

and certainly there was no time when He was not religious. It is all the more significant that in His life-as so often in our own-a movement of spiritual exaltation such as accompanied the experience of His Baptism was followed by its psychological reaction in the Temptation in the Wilderness; while in the narrative of His Passion the veil, which save for rare glimpses conceals from us His inner life, is lifted to show Him to us agonizing in the Garden and (so far as subjective feelings went) forsaken of God upon the Cross. And upon that cry of dereliction not a little may be based. Surely, never was our Lord in reality less forsaken of God than when $\mathrm{He}$ felt Himself forsaken. Surely, we have here the supreme instance of the gap which may exist between feeling and reality, of the distinction between sensible assurance and essential religion.

The essence of religion, if we are to learn it from the life of our Lord, does not consist in a state of consciousness, or a sense of God's presence, but rather in an attitude towards God of the personality as a whole, and most fundamentally of the will. Not feeling, but 


\section{RELIGION \& TEMPERAMENT 13}

action, is its characteristic expression; not consciousness of the Divine, but rather that deliberate dedication to God of the whole self and of its every activity, which energizes in service and culminates in sacrifice. Religion is constituted, not in an experience which men enjoy, but in a service which they renderan oblation which they offer. God's service may indeed be perfect freedom; it may be attended by fulness of joy; it may lead at the last to pleasure for evermore; but that is not the point, and cannot rightly be erected into the end of religious activity. "To glorify God "- that is the end of man's religion, and to 'seek that end is to seek God's Kingdom and His righteousness. "To enjoy Him for ever"- that is not to be the end or motive, though it may be the outcome, of religion; it is one of the things which are eventually "added unto" those who seek first the Kingdom.

Traditional moral theology bears out these contentions. It is a commonplace of all spiritual writers to forewarn the beginner in the life of religion that permanence of sensible devotion is not to be expected. Fervour 
alternates with " dryness," the sense of God's presence with the apparent withdrawal of it; the soul passes often under the shadow of a "Dark Night" in which it is deprived of "comfort" and interior consolations. "When spiritual comfort is given thee from God," writes à Kempis, "receive it with thankfulness; but understand that it is the gift of God, not any desert of thine. Be not puffed up, be not too joyful nor vainly presumptuous. . . When consolation is taken from thee, do not immediately despair ; but with humility and patience wait for the heavenly visitation. ... This is nothing new or strange to them that have experience in the way of God; for the great saints and ancient prophets had oftentimes experience of such kind of vicissitudes. ... I I never found any so religious and devout, that he had not sometimes a withdrawing of grace, or felt not some decrease of zeal." 1

To yield at such times to depression or despair, to acquiesce in sluggishness and spiritual inertia, is to be guilty of the sin

1 De Imitatione Christi, lib. II. cap. ix. (De carentia omnis solatii). 
of acedia or accidie; but the experience, in itself, is so far from being sinful that it may, if used aright, prove fruitful in spiritual profit and advance. The late Bishop Paget, whose discussion of acedia has become a classic, quotes a French writer as saying that interior discouragements, provided only that they do not arrest its progress altogether, carry the soul forward in the way of faith more rapidly than anything else; and himself remarks that " those who ... sustain throughout the days of darkness the dutiful direction of desire and will may find that, in the weary hours of the night, they have been moving more directly and more speedily than they thought towards the haven where they would be. For there is, I think,"-he adds - "in the spiritual life an experience somewhat like that of which a trawler in the West of England told me. He said that sometimes through a dark night, when on the deck the air is dull and heavy, and there seems to be a dead calm, there may be wind enough astir, not many feet above the sea, to catch the topsail and carry the sloop along, so that at daybreak it is found farther on its course than the men, for all 
16 DOGMA, FACT \& EXPERIENCE

their keen sense of seafaring, had ever thought it could be." ${ }^{1}$

Suggestive, too, in this connection is the contrast between Christian and Pagan ethics. It is noteworthy that all the virtues of the Aristotelian canon-courage, temperance, and the rest-are self-contained states of the virtuous man himself. They are capacities or habits of the soul, developed by exercise and proper training and informed by reason; an environment and opportunity is of course required for their development and for their display; but in the last resort they are entirely self-centred adornments or accomplishments of the good man ; and it is significant of this self-centredness of the entire conception that the qualities of display ( $\mu \in \gamma a-$ $\lambda o \pi \rho \epsilon \pi \epsilon i a)$, and high-mindedness or proper

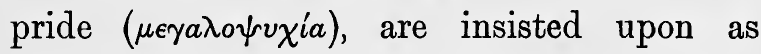
integral elements of the ideal character.

On the other hand the three characteristically Christian virtues - faith, hope, and charity-all postulate and imply Another besides the self, who is their object, and to

1 Paget, The Spirit of Discipline, Preface to the seventh edition, p. xxxi. 
whom they are directed. The Christian character is centred not upon the self, but upon God. Its formula is never "my soul and its virtues," but always "my soul in its relation to God, and in virtue of that, to my brethren." From which it immediately follows that for self-complacency (which was demanded by the Greek scheme) there is, in the Christian scheme, no room.

Good works, it is asserted by an Article of Religion which has been perhaps unfairly criticized, may have under certain conditions the nature of sin. It is not asserted that they are sinful, but that they have the nature of sin. What is the nature of sin, and why do men ever commit sin? The only answer is that they do it because they like it; and good works-such as the exercise of "natural virtues" - have the same nature as evil works just in so far as they are done merely because we happen to take pleasure in them, and not as part of that entire oblation of our lives to God, through union with the oblation of our Lord, in which Christianity essentially consists. We are to take pleasure, not in our own virtues, but in God's service. Our pagan 


\section{DOGMA, FACT \& EXPERIENCE}

virtues and good qualities require to be redeemed; and their redemption is effected just in proportion as they are brought under the sanction of the Christian sacrifice by being performed not for our pleasure but for God's glory. The Christian redemption of man consists fundamentally in his salvation from the self-centredness of natural virtue by the restoration of the proper relation of the creature to the Creator.

We are now, perhaps, in a position to arrive at a juster view of the true relation between religion and temperament. It is not that religion is a peculiarity characteristic of a special type of temperament; on the contrary, it is as universal as the claim of God's love upon the free devotion of His creatures. But because men's temperaments vary, religion will be variously manifested. There will be devotees and mystics, poets and contemplatives, on the one hand ; and men of affairs and practical, matter-of-fact people, on the other. There will be those whose work is their prayer and those whose prayer is their work. There will be devout people and pious people-because to be such is the trend of 
their temperament; and there will be people who are neither the one nor the other. There will be "religious" and there will be "seculars," just as there will be men of thought and those who are predominantly men of action; there will be sociable and expansive people, and there will be recluses-men who see visions and dream dreams, and men who ply the daily round and the common task. "These all worketh that one and the self-same Spirit, dividing to each man severally as $\mathrm{He}$ will." Each man's gift and each man's temperament, of whatever nature it is, comes from God, and needs to be redeemed by consecration to His service. But the man of devout temperament is not necessarily nearer salvation than his brethren. If he turn Pharisee and judge his brother, or if by reason of the exceeding greatness of the revelations he become exalted overmuch, his very piety may turn to his undoing. Our Lord has taught us to judge not according to the world's scale of values; the harlot and the publican may be found entering the Kingdom before the Pharisee; and spiritual pride-the besetting sin of devout people-is the one sin which, accord- 
ing to the Christian standard, is altogether deadly.

The practices of devotion-frequent churchgoing, prolonged prayer and meditation, the saying of offices and the daily frequentation of the sacraments-depend for their possibility in part upon opportunity and circurnstance, and even more upon the possession of leisure. Anything beyond a minimum of such observances is, and must always be, the spiritual luxury of the few. Let us beware of so defining religion as, by making it dependent either upon temperament or upon circumstances, to destroy the catholicity of its appeal. If Christianity is to be a religion for all men, then we must be able to say that the soldier in the trenches, the shoeblack at the street corner, or the sweated seamstress in her garret, can be as religious as the Benedictine in his cell or the nun at her prayers in the convent chapel. Each is religious just in so far as he is fulfilling his vocation, just in so far as his life in its every activity is truly offered to God. Prayer may have the nature of sin, and blacking boots the nature of sacrifice.

One thing is ncedful-the oblation of the 


\section{RELIGION \& TEMPERAMENT 21}

self to God; for the rest, Martha has claims to recognition equally with Mary, and we shall refuse to exalt either above the other. " The eye cannot say to the hand, I have no need of thee; or again the head to the feet, I have no need of you." "Pure religion and undefiled before our God and Father is this, to visit the fatherless and widows in their affliction, and to keep himself unspotted from the world." 


\section{II}

\section{DOGMA AND HISTORY}

THIS essay is an attempt to define some of the issues raised by the "modernist" controversy which was at its height in the years 19071909. The term "Modernism" is here used, not in the general sense in which it is applicable to the work of all those who, in each successive generation, attempt to interpret Christianity to the mind of the age in which they live, but in the proper and technical sense, according to which it denotes the attempt made in the opening years of the present century, by a group of Catholic thinkers of which the Frenchman Loisy and the Irishman Tyrrell were acknowledged leaders, to sever the link between History and Dogma by combining an affirmation of the spiritual and religious truth of the dogmas of the Historic Church, with the claim of freedom to deny any or all 
of the alleged facts of history with which the said dogmas had hitherto been held to be implicated.

Modernism was an attempt to succour a distressed orthodoxy; and the intellectual situation which it aspired to meet was one that was bound to arise so soon as the claim was conceded that methods of critical inquiry analogous to those employed in secular history should be applied equally to those documents and alleged facts which lie at the basis of the Christian tradition. It is not, indeed, that the documents in question are as a whole less trustworthy, or the alleged facts less well supported, than is the case in other departments of historical investigation. It is rather that all history is more or less debatable ground; that individuals will always differsometimes widely, sometimes only in detailsin their estimate of historical probabilities; that there is always a certain case for the historical sceptic; and that the attainment of demonstrative certainty with regard to alleged happenings in the past is in the nature of things impossible. Especially does the very desire to find a thing true operate, in many of 


\section{DOGMA, FACT \& EXPERIENCE}

the best minds, as a predisposition towards scepticism; for men do not desire, in that which concerns them nearly, to be selfdeceived. The rationabile obsequium of faith is something wholly other than the credulity which suffers historical judgment to be overridden by the will to believe; and the just balance in such a matter is both difficult of attainment and incapable of verification when attained.

It was inevitable, therefore, that the attempt to isolate the investigation of the early documents of Christianity as a purely historical problem, and to find a basis for religious faith in the results-however stoutly affirmed to be "assured "- of historical "science," should break down. The successive phases of opinion in the sphere of historical criticism are as transient and as kaleidoscopic as are the everchanging hypotheses which from time to time are dominant (shall we say?) among physicists with regard to the constitution of matter. And in the meantime the religious man-as a recent writer voices his complaint-cannot afford to be dependent upon " a yearly statement from Dr. Sanday, comparable to the 
weather report, as to "What we may still believe.' " 1

Meanwhile the modern historico-critical attitude of mind had familiarized us all with a distinction, very commonly drawn, between fact and value, between events and their interpretation. The distinction in question is one which, if made absolute, is in the long run of very dubious validity from the point of view of the philosopher. In strictness it is impossible ever to isolate an event as bare fact: there are no "bare facts" of history, ascertainable as such. The element of valuation and interpretation is already present in the mere fact that certain particular facts are selected for investigation and isolated from their historical context as especially significant or interesting. The very documents which form the historian's data are themselves already in some degree interpretations; they are never bare statements, if only because they are never complete statements, of " what actually occurred."

Moreover it is not true that the historian (for all his claim to be "scientific") approaches his

1 R. A. Knox, Some Loose Stones, p. 35. 
problem in independence of presuppositions. There is not, and there cannot be, such a thing as "impartial" history, in this sense of the words. A certain view of the universe, a particular mental furniture, a definite outlook, is presupposed by every historian who ever wrote. It is something which he brings with him to his work. It may be modified by what he finds there, but it certainly is not created by what he finds. A historian, for example, who believes with Carlyle that history is the biography of great men, will base upon identical data a reading of the course of events widely divergent from that produced by one who sees in history only the working out, as by a kind of immanent logic, of impersonal tendencies and principles. The Greek history of a Grote is coloured by the writer's faith in democracy, the Roman history of a Mommsen reflects the Prussian idealization of Caesar. There is an element of hero-worship in all biography, and in every historical writing the facts are coloured in proportion as the historian's sympathies are engaged. Sympathy is, none the less, essential to insight, and the pretence of neutrality may easily prove a 
more fatal disqualification for right judgment even than the bias of a partisan. To take an illustration from contemporary events, the causes of the present war are estimated very differently by historians of equal candour and sincerity upon either side. A study of the available facts and documents has convinced German writers of eminence that the war is, in essence, one of self-defence for the German Alliance; while practically the whole world outside Germany, Austria, and Turkey is convinced, on the evidence of the same documents and facts, that Prussia was the aggressor. Estimates so contradictory cannot both be true, and it is obvious that national predilections and sympathies enter in, upon both sides, to affect men's judgment. It is improbable, perhaps, that either the British or the German contentions are in all respects true without qualification; but it is still more improbable that a right judgment is to be reached by the simple process of striking a balance between them, and concluding lamely, in the manner of a Greek chorus, that there is much to be said upon both sides. To suggest that the British presuppositions are 
upon the whole right, and that the German presuppositions are upon the whole wrong, may sound absurd: and it would be absurd if it were based merely upon "patriotism." But the suggestion may have more than "patriotism" behind it. It may happen, in this particular case, to be true; and in that event, "British" sympathies, so far from distorting judgment, would be a guide to right judgment of the facts. The true ideal, in short, in historical criticism is not to eliminate the "personal equation." It is to bring the right "personal equation" to bear.

Nevertheless, though the distinction, for the reasons assigned, cannot be made absolute, it may be granted that it is not nonsense to speak, with a certain relative validity, of a distinction between fact and interpretation; and that in particular it is plausible to draw a certain distinction between the facts, real or alleged, which are at the basis of the Christian creed, and the interpretation which, in that creed, the Church is putting upon the facts. Will the facts bear the interpretation? Or, even if they will bear it, do they necessitate it? The problem being considered from this 
point of view, there arose a certain parting of the ways. If, in regard to Christianity, the possibility of a distinction between fact and interpretation be once granted, it is obviously possible to concentrate attention either upon facts, discarding as far as possible interpretations, or upon interpretations, discarding facts. The former method underlies the work of all writers of the modern school of Liberal Protestantism; the latter was the method of the Catholic modernists.

Liberal Protestant writers, inheriting as a tradition from Ritschl the repudiation of religious metaphysics, are for the most part metaphysically agnostic. Their aim is to arrive, by a process of critical inquiry, at a positive and strictly "scientific" account of the life and career and teaching of the historical Jesus, and then to consider what significance the result-regarded as a purely human phenomenon-may possess for humanity at large. It is immediately obvious, indeed, that this procedure is not really to discard interpretations but to substitute a new interpretation, or set of interpretations, for the old. To suppose the contrary is on the one hand to 
conceive of history as a "science" in a sense in which it is illegitimate so to regard it, and on the other to degrade it to a mere investigation of phenomenal sequences, precluded by a rigorous metaphysical agnosticism from every attempt to determine causes or meanings. The writers of the Liberal school have, however, shown themselves singularly deficient in any sense of the obligation to criticize the presuppositions of their own method : and the general upshot of their inquiry has been, in minds of a certain temper, pure scepticism; in natures already temperamentally devout, a pietistic attitude towards life and towards the universe as a whole, determined, in ways which are seldom clearly defined, by an interest in, an admiration for, or in some cases even a virtual worship of, the historical figure of Jesus. It must be explicitly recognized that the Christ of the Synoptic Gospels is discovered in the actual lives of many Liberal Protestants to be invested with a religious value and function which goes beyond anything which is either explicable or justifiable in terms of Liberal Protestant doctrine-or lack of doctrine-with regard to 
Him. It remains true, however, that Liberal Protestantism, regarded as an intellectual system or position, is not Christianity in any sense which the word has hitherto borne, inasmuch as in it the fundamental Christian dogmas are ruled out upon principle as inadmissible, and it is consequently impossible to interpret the story of Jesus as in the old sense a Gospel of the power and grace of God.

In contradistinction to all this, "Modernism" sought, as aforesaid, to take precisely the opposite line. It professed a complete indifference-so far as any effect upon religion was concerned-towards historical criticism and all its works; it was ready to discard facts, or supposed facts, if need be ; it was content to cling to interpretations. It made its appeal to Christian, and especially to Catholic, experience. Whatever might or might not be the truth as to the career and teaching, or even as to the existence, of the historical Jesus, the fact remained that human lives through a succession of generations had been moulded and touched to fine issues by the practice of Catholicism as a dogmatic and institutional system. Might there not be a 
truth of faith capable of maintaining itself in independence of so-called truths of fact? Did not the dogmas of the Christian creed represent in any case "values" of proven efficacy in the life of the human spirit, and was there any need to ask for anything more?

The ablest statement of the modernist view of dogma is that given by Edouard Leroy in Dogme et Critique. ${ }^{1}$ The difficulties which lead perhaps a majority of the "intellectuals" of our day to reject the dogmatic creed of historical Christendom arise, thinks Leroy, mainly from the tendency to construe dogma in an intellectual sense, as a contribution to speculative knowledge. Consider, for example, the dogma "God is personal." To say nothing of the difficulties raised by the word "God," in what sense are we to understand the word "personal"? To assert personality of God in the same sense as we assert it of man is to be involved in an anthropomorphism which Catholics and agnostics are at one in repudiating. On the other hand, if, asserting the personality of God, we explain that we mean by the term something quite incommensurable

1 Paris, Librairie Bloud et Cie., 1907. 
with the personality of man, the objection at once suggests itself, why then use the same word for two different things? Analogous difficulties might be raised with reference to other dogmas of the Christian faith; nor is there any way of meeting them, until it is realized that they are dependent one and all upon a misconception of the true nature and function of dogma as such.

Leroy then proceeds to expound his own proposed alternative view of dogma, in opposition to the intellectualist conception which he rejects as plainly wrong. He points out, in the first place, that dogma is, from an intellectual point of view, negative rather than positive in function. It does not so much determine positively what is true, as exclude and condemn certain errors. As instances he selects the dogmas of the Real Presence and the Resurrection in addition to his own previous example, viz. the personality of God. The dogma that "God is personal" is to be regarded rather as negating the conception of God as impersonal or sub-personal, than as defining positively His nature. It gives us no new positive conception, still less does it 


\section{DOGMA, FACT \& EXPERIENCE}

guarantee the truth of any particular system of metaphysics; but it warns us that such and such forms of Pantheism are false and to be rejected.

Similarly the dogma of the Real Presence is to be taken, not as a positive theory of the manner or nature of the association of our Lord with the Eucharist, but as negating the doctrine of a real absence, and as stigmatizing as inadequate the view that the consecrated Host is a mere figure or symbol of the Christ.

The Resurrection as a dogma of faith is to be explained in the same way. It embodies no theory of the mechanism of our Lord's rising or of the nature of His post-resurrection life. But it excludes such ideas as that death set limits to the action of Jesus upon things in this world. It means that Christ comes amongst us and lives amongst us still; and that, not in the sense in which a bygone thinker (for example) may be said to live on as a memory and an influence among subsequent generations, but in the sense that $\mathrm{He}$ is our literal contemporary. In a word, death was not for Christ, what it is for the generality of mankind, a cessation of practical activity among the living. 
Intellectually, then, the function of dogma is negative; it is the ruling out of certain positions as inadequate. But dogma has, of course, a positive function also; and this, according to Leroy, is not speculative but practical. "Dogma," he writes, "has above all a practical significance. It is a prescription d'ordre pratique." It is the formula of a rule of practical conduct.

To illustrate once more by the same three examples :

(1) The dogma "God is personal" means, "Behave in your relations with God as you would in your relations with a human person."

(2) The dogma "Jesus is risen" means, "Be in relation to Him as you would have been before His death, as you would be if confronted by a contemporary."

(3) The dogma of the Real Presence means, "Act in relation to the Host as you would in relation to Christ Himself visibly present."

And so on as regards the other dogmas of the Church.

Thus far Leroy's position might appear to be simply a crude religious pragmatism; it is 
saved, however, from this implication by two very important provisos:

(1) Every dogmatic precept of the Church involves the implicit affirmation that Reality is objectively of such a character as, in some real sense, to justify as right and reasonable the conduct which the dogma prescribes; and

(2) The acceptance of dogma as a rule of life must not exclude the religious duty of thought; and qua thinker the Christian must aim at an intellectual synthesis of the values of his creed as determining the nature of Reality.

Leroy's is by far the ablest, the least inadequate, the most carefully thought out, of all the various forms of Catholic modernism. It is reached, moreover, not by way of an antithesis between dogma and history (he is not interested primarily in historical criticism or concerned to maintain historical negations), but by way of a positive analysis of the nature of dogma as such. He does not, with some of the extremer modernists, deny the connexion between the Christ of faith and the Jesus of history, but on the contrary implicitly affirms their identity. And in fact, if we consider it 
purely as a philosophy of the significance and function of dogma in the life of a Churchman, I am disposed personally to accept his view. It does not, however, go to the root of the question of truth; it merely raises it and leaves it unanswered. "Dogma interpreted as a rule of conduct involves the implicit affirmation that ultimate Reality is such as to justify the conduct prescribed." Precisely : there the whole problem resides. How much or how little need those words imply? Two comments may be made.

(1) It is perfectly intelligible that one who is already a devout and practising Christian might continue to be such upon the basis of a very considerable agnosticism as to ultimate questions. It is intelligible, for example, that he might argue somewhat in this way: "These practices of prayer and sacrament, and this dogmatic Catholic creed, have brought spiritual life and strength to me and to others in the past and can still do so in the future. I may be doubtful enough as to the alleged historical origins of my religion, and I may be unwilling to commit myself speculatively to Theism in any orthodox sense of the term; 


\section{DOGMA, FACT \& EXPERIENCE}

but I believe that there is a spiritual reality at the back of the world, and through these particular creeds and forms and symbolsimperfect, crude, and fumbling as I take them to be-I have found by experience that my finite spirit-so runs at least my dream-may hold communion with the Infinite."

But (2) it is difficult to see how so agnostic a presentation could ever constitute an effective basis of missionary propaganda, or indeed could be expected to make much of an appeal to any one not already - as it werewithin the Christian fold. It is a possible basis of religion for such as hold it; but it is surely an entirely different thing from the traditional Christian faith. And if we are to consider, not the man of temperamental piety and natural virtue, but the man of strong temptations in the rough and tumble of life, it appears to me to be futile to expect the recommendation by another person of a particular method of human approach to the Infinite as salutary and beneficial, to achieve moral miracles such as used to be effected by the doctrine of a real incarnation and atonement wherein God approached man. There is all 
the difference surely between religion advocated as a possible view of the universe and a helpful attitude to life, and religion proclaimed as the truth of God Himself and the very core of what life means; between Pantheism grown sentimental, and the Gospel of the living God.

For Christianity has from the beginning been proclaimed as a Gospel; and it may conduce to clearness if we attempt to summarize shortly the content of that Gospel, from the point of view not of the philosopher but of the plain man.

In brief, then, Christianity has always started from the assumption of a living personal God, maker of heaven and earth, upon whom all things depend, and who is throughout the length and breadth of His creation ceaselessly operative and active. Man, made for communion with God, is asserted to be in a state of fallenness from such communion, the fault being considered to lie not upon the side of God but on that of man. The result is a sense of spiritual dissatisfaction in man's life, a seeking after God that is perpetually frustrated by an 
inherent inability on man's part to attain. And man is fain to set up for himself-as witness all heathen religions and religious philosophies_imagined divinities which are emphatically asserted by Christianity to be mere $\epsilon^{\prime} \delta \omega \lambda a$ - idols - not the real thing: whether they be literal idols of wood and stone or the hypostatized projections of man's own ideal is by comparison of small account.

Thus far an impasse, a problem of human need which no striving of the human spirit can of itself supply. Doubtless there are qualifications to be made-"God left not Himself without witness," and so forth-but speaking broadly, Christianity asserts an emphatic doctrine of man's impotence to find God, as the very presupposition of its own essential Gospel of a definite historic act, manifestation, or advent, whereby God once for all found man.

For if heathen religions are the religions of man's search for God, Christianity is the religion of God's search for man. It is asserted that in the definite historic person of Jesus Christ the Life once for all was manifested, revealed in suffering and triumphant through death and resurrection; that the Eternal 
Passion of selfless Love, which was at the very heart of God Himself, in the fulness of time came forth and took hold of the human race, in such wise as to make men, in virtue of that adoption, sons of God; further, that that divine act, which we are to see in the Incarnation, Passion, and Resurrection of the Christ, is not merely an event of the remote past, but something for ever continued and perpetuated in the Church, an unending process whereby Christ is daily born anew in human hearts and lives, gives Himself sacramentally to be their spiritual food and drink, inwardly transforms them into His likeness by the effectual dynamic of His communicated Spirit, and moulds them into realized oneness with His Person.

Doubtless any alleged facts-and the Christian facts in particular in proportion to their transcendent importance-must, if accepted, have their implications for philosophy. But it is, emphatically, as a Gospel of fact rather than as a theory of metaphysics that this Christian message has historically been proclaimed. It implies indeed a doctrine of God, and of the relation of the Eternal to 


\section{DOGMA, FACT \& EXPERIENCE}

the process of events in time, which may and does suggest difficulties to the philosopher. It has been elaborated and sophisticated by theologians in ways which are not always either intellectually tenable or morally edifying. But its essential character as a simple and effectual Gospel for simple people has persisted unchanged through the centuries; and it has proved its power in the conversion of sinners and the reclamation of the degraded, has interpreted the issues of life and destiny for multitudes in many generations, and has borne fruits of ethical beauty and spiritual force of character in those whom we call its saints, which are consonant with the hypothesis of its truth, and are otherwise less easily to be explained.

We have spoken of it as a Gospel of fact - the proclamation of certain events as true. It may be characterized still more precisely as a Gospel of act-the proclamation of an eternal act of God, wrought indeed in one sense at a definite time and place, and yet continued for all time as a perpetual dynamic power, a perpetual putting forth by God for man's salvation of a transforming spiritual 
energy - "My Father worketh hitherto, and I work." The initiative, the energy, the power and activity which underlies the phenomenon of Christianity is proclaimed as God's act throughout. Man's part is but to yield himself, to correspond and not to resist; and even so, the process, for example (so it is asserted), by which a man comes to Christ is not his act but God's - "no man cometh, except the Father draw him" : it is something which is wholly the gift of God-" not of works, lest any man should glory."

The French Catholic writer, Laberthonnière, in his book Le Réalisme chrétien et l' Idéalisme grec, ${ }^{1}$ draws out very suggestively the contrast in this respect between the view of the world which is characteristic of Greek philosophy and that which is implied in Christianity. The former tends always towards a static conception of the universe, in which (abstraction being made from the individuality of concrete particulars in the world of time and change) Reality is envisaged as a hierarchy of ideas cohering logically in the ultimate unity of a single Supreme Idea or Absolute,

1 Paris, P. Lethielleux, 1904. 
44 DOGMA, FACT \& EXPERIENCE

indifferently to be described as God or Nature, but in any case something fixed, final, determined: an eternal, impersonal, changeless Fact.

In contrast with this the Christian worldview is dynamic, concrete, individual. In the actual world no one existence is ever the merely logical consequence of another, because no two particulars are ever identical. Christianity, instead of making abstraction from the individuality of particulars, seeks to take account of their actual character as concretely presented in experience by conceiving them positively as products of the Divine activity. God is conceived no longer as merely a supreme Idea, but as a supreme Personal Being, alive and active-" un Dieupersonne qui est une puissance d'agir"-_"a God-person who is potential activity." So far from being an idea or an essence reposing statically in an eternal calm, the God of Christianity is rather the ceaseless activity of an eternal life : a life, moreover, which is not merely intrinsic to the Divine Being, but is for ever putting itself forth as a creative energy which constitutes and sustains a world 
other than God, though a world which apart from God could not exist. It follows that God is present to the world not merely as ideal, exemplar, and final cause ; He is present actively and really as an efficient cause, ceaselessly co-operant in all events. His activity is a transcendent reality which penetrates the world and becomes immanent therein, determining its course, its nature, its destiny; assuming consequently the form of events in time, and becoming an integral factor in the history of mankind and in the lives of individual men.

The history of the world and of man is from this point of view, in part at least, a history of God's action; and the knowledge of God must consequently be sought not in the abstract contemplation of Him as an idea or principle, but concretely through His selfrevelation in history, and pre-eminently (according to Christian teaching) in those alleged facts, or rather acts of God, which underlie the Christian tradition and form the content of its creed.

Christianity, therefore, in so far as it is doctrinal, is not an abstract doctrine, not a 


\section{DOGMA, FACT \& EXPERIENCE}

view of the world, such as was the ideal of the Greeks, and is the ideal of the pure philosopher to-day: it is an apprehension of the inner significance of certain events past and present in which God is pre-eminently operative and active. In brief, it tells how God came and how God comes to man. To distinguish with the modernist between fact and interpretation, between history and dogma, is from this point of view illegitimate. It is, in effect, to Hellenize the Gospel; it is to view it as a Greek philosopher might view it-as something to be contemplated and analysed from outside. An act, in contradistinction to a fact, is properly apprehensible and intelligible only from within. Its meaning, purpose, and value are intrinsic ; they belong to its essential character qua act ; they are a part of what it is, and if abstraction be made from them the act itself is imperfectly apprehended; they are by no means to be regarded as values read into "what really happened" by external observers after the event; they are and constitute "what really happened."

Assuming that Laberthonnière has correctly formulated the essential Christian position, it 
is immediately obvious that a Gospel so conceived cannot possibly be independent of all imaginable conclusions, either of historical science on the one hand or of philosophical speculation on the other. Philosophically, for example, it will be in conflict with any metaphysical school which is unable to concede the validity of its implied conception of God; while on the side of history, though not indeed necessitating a priori any particular order of events, or prescribing beforehand to historical criticism the conclusions at which it shall arrive as to the external character and phenomenal sequence of the occurrences which presumably underlie the Gospel stories, it is yet inconsistent with the acceptance of any such reconstruction of the external order of events as would render inadmissible their interpretation as from within in terms of the doctrine that "God was in Christ reconciling the world unto Himself." Many questions may indeed be left open and regarded as fairly debatable: such questions, for example, as the duration of our Lord's public ministry, whether it lasted for several years or only for a few months; questions with regard to specific 


\section{DOGMA, FACT \& EXPERIENCE}

events in the ministry, whether, for example, He did or did not heal this or that sick person, feed 5000 , or walk on the water; or even-a profounder issue, and one much debated in theological circles of late-what it felt like to be Messiah, and how much our Lord knew about it at the time : but whatever answer or answers be given to questions such as these, the maintenance of the validity of the traditional Gospel does appear to involve the assertion that to interpret the history otherwise than as an act of God in Christ for man's salvation is to miss the inner truth of what in point of fact occurred.

Now, that what is called Christian experience is consonant with, explains, and is explained by, such a theology as I have suggested will hardly be denied. Bearing in mind Laberthonnière's contrast between the Christian and the Greek conceptions, we may remind ourselves that the history of the thought of Europe since the Renaissance has been predominantly a history of Hellenic conquest-especially in philosophy-and of the rise of natural science and scientific method. Orthodox Christian doctrine has in 
consequence found itself threatened upon both its vulnerable sides-both by the widespread vogue of metaphysical theories inconsistent with its idea of God, and by the supposed conclusions of historical science affecting to dissolve away into myth and legend its basis of reputed fact. It was indeed out of such a tension (not to say conflict) between Christian theology upon the one hand, and secular thought and science upon the other, that the phenomenon of Modernism, such as this paper has discussed it, arose. It arose as an attempt, at a time when the Philistines appeared to be laying profane hands upon the ark of God, to remove it out of their reach.

The ark is not to be saved from Philistine violence at the cost of its surrender by the faithful : and the Gospel, divorced from its basis in history, must needs lose its essential power.

To say this is not to render unnecessary or illegitimate the process of Biblical criticism; neither is it to prejudge in detail its results. Our faith, it has been recently remarked, is not dependent either upon "the credibility of Judges or the edibility of Jonah." ${ }^{1}$ I

1 R. A. Knox, op. cit. p. 20. 
50 DOGMA, FACT \& EXPERIENCE

would add that it is not dependent either upon the authorship of " $Q$ " or the historical character of the Fourth Gospel. When once the belief in an historic incarnation is granted, the attempt to investigate, to understand, and to interpret the actual facts as to the form and manner of it at once becomes important : and (for all those who by education and training are capable of undertaking it) it is a religious duty and privilege. Here is at once the justification and the value of the whole process of modern historical criticism as applied to the Gospels, and of the successive attempts which have been made to reconstruct and to interpret the portrait of the actual historical Jesus. Apart from such a belief, on the other hand, the investigation of Christian origins becomes simply a highly technical department of archaeology, which can be of interest only to specialists. But it is important in either case to recognize the limitations of the historical method: and if the portrait of the Christ, as provisionally reconstructed by the critics, should in any given case prove such as to be incapable of interpretation in terms of Christian dogma, then clearly we should be face to face 
with the choice between abandoning the Gospel and modifying the presuppositions of our criticism.

Enough, it may be hoped, has been said to make clear both the sense in which the modernist apologetic is of value, and also the point at which it would appear to break down. On the one hand, it is possible to accept Leroy's interpretation of the nature of dogma, and to agree with the modernists in taking the proven efficacy of Christianity in the spiritual experience of the Church as the starting-point of any argument with regard to its truth. On the other hand, it does not appear that the divorce of dogma from history can be made absolute, in the manner in which the Roman "modernists" desired. Christianity is, and must incorrigibly remain, an historical religion. That has unquestionably been its character from the beginning; and apart from the fundamental conceptions of the revelation of God in and through history, the self-manifestation of God in Christ as operative and active for man's salvation, and the continuance of the work of Christ through the Spirit in the Church, Christianity changes its character, 


\section{DOGMA, FACT \& EXPERIENCE}

and becomes something quite other than itself. We may take the efficacy of Christianity and the witness of Christian experience as our starting-point; but as we pursue the argument, we shall be driven either to asperse the validity of that experience, and to deny that it is what it appears and claims to be, or else to affirm the truth of the Gospel, at once historical and dogmatic, as its only sufficient ground and explanation. As I have already put it, we must be able to affirm that as a simple matter of actual fact God was and is in Christ reconciling the world unto Himself. 


\section{III}

THE RESURRECTION AND THE LIFE

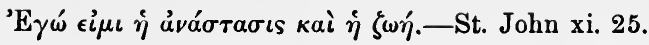

"We are not these changing bodies which we bear."

WestcotT.

THE question of the fact or the nature of our Lord's resurrection from the dead is one which may be treated in very various ways. It is possible to approach it, in the first instance, from the point of view of the literary critic. The relevant New Testament documents are critically tested and compared, and the result, broadly speaking, is to establish the following positions:

(i.) The list of appearances of the Risen Lord in 1 Cor. xv. 1-8 is earlier in date than any of the Gospels, and is therefore in a literary sense independent of their narratives. 


\section{DOGMA, FACT \& EXPERIENCE}

(ii.) Of the four canonical Gospels St. Mark's is the earliest, but the Marcan narrative breaks off after the words "for they were afraid" in St. Mark xvi. 8, the original conclusion being lost and the passage which now stands in the text as St. Mark xvi. 9-20 being a later addition intended to supply the place of the missing verses.

(iii.) The compilers of the first and third Gospels wrote with St. Mark's Gospel before them, and are in general dependent upon Marcan material for the narrative portions of their work, but it is impossible now to determine whether either of the very different versions which they give of the events after the resurrection is a reproduction, wholly or in part, of the lost Marcan ending.

(iv.) The Gospel according to St. John, although the latest of the four in point of date, shows no clear signs of literary dependence upon the other three.

With the establishment of these conclusions the function of documentary or "higher" criticism is, properly speaking, at an end : yet it is obvious that the problem cannot simply be left at the point which has thus far been 


\section{RESURRECTION \& THE LIFE 55}

reached. Questions belonging to " historical" criticism proper arise out of the "higher" criticism of documents as inevitably as the "higher" criticism itself arises out of the "lower" or textual criticism of manuscripts and readings.

To the historical critic the problem presents itself somewhat as follows: the conclusions of higher criticism with regard to the mutual relations of the sources being taken for granted, how may the occurrence in the several documents of the resurrection narratives, in the somewhat conflicting forms in which we have them, be most adequately and truly explained ? Is the hypothesis of pure legend historically plausible? Or are we driven to postulate an actual historical event, or series of events, as underlying the stories and serving to explain their growth? And in the latter case what must be assumed to have been the precise nature of the event or events in question?

These and similar questions arise inevitably from the investigation of the New Testament evidence, and they are questions to which a purely literary criticism is from its very nature unable to supply an answer. They belong to 


\section{DOGMA, FACT \& EXPERIENCE}

historical criticism proper : and when this has once been realized, it becomes evident that a number of considerations have a bearing upon the issue which in a narrowly documentary investigation would be irrelevant. We have to take account of the circumstances of the time, the political, social, and religious backgrounds of the story, the psychology of human evidence in general, the psychological tendencies of the apostles in particular. The results of the comparative study of stories of " miracles" occurring in other contexts and in the records of other religions become relevant to the issue. So also do considerations arising from the philosophical criticism of the conception of "laws" of nature, the speculations of physicists as to the ultimate constitution of matter, the theological presuppositions arising from belief in the Incarnation on the part of those who, upon other grounds, accept that doctrine.

The problem becomes at once exceedingly complicated, and the range of relevant considerations exceedingly wide. At each successive stage of the investigation the door is thrown open to increasingly divergent judg- 
ments. For history is in the last resort not a science, but an art; and the attempt which in the last generation was made to treat it as "a science, no more and no less" has broken down. The conclusions of the historical critic are in reality determined rather by the soundness of his intuitions than by the correctness of his scientific method: and no two investigators working independently are likely to estimate the relative values of conflicting pieces of evidence in precisely the same way, or to draw from a given complex of data identical conclusions.

This does not, of course, mean that the whole of history is in dispute, or that in the investigation of past events there is no such thing as a reasonably assured conclusion. With regard to the broad outlines of history there is in practice something like a consensus; and to raise doubts, for example, as to the murder of Julius Caesar would be generally felt to be unreasonable. There remains, nevertheless, in all determination of historical truth a margin of uncertainty; and in proportion as any issue of importance is involved, the area of dispute is apt to be more 
58 DOGMA, FACT \& EXPERIENCE

widely extended. 'The historian's estimate of the evidence is determined by his sense of inherent probabilities. The "personal equation" " is involved, and in drawing conclusions with regard to such a question as that of the resurrection a man's whole view of the universe necessarily and rightly comes into play: certainly to affect to treat of it purely as a problem in the estimation of documentary evidence is to approach the subject in an impossibly abstract way.

So far, indeed, as it is possible in any degree to isolate the so-called "critical" problem in abstraction from wider issues, it must be said that the view of our Lord's resurrection which has hitherto been regarded as "orthodox" in the Christian Church-if upon other grounds we regard it as open to us to adopt it-accounts adequately for the existing evidence, and perhaps more naturally explains the narratives than any other. The existence and currency of a story can always be accounted for most simply by the hypothesis of its truth, supposing it to be regarded as intrinsically probable or credible; and dis-

1 Cf. supra, pp. 25 sqq. 
crepancies in the details, as establishing the independence of the witnesses, do but add to the strength of their testimony to the main event. Students of the psychology of evidence know very well that complete unanimity with regard to the details of any story which purports to rest on the testimony of a number of witnesses is never reached except as the result of collusion. But the orthodox view, though the simplest hypothesis for those who regard it as admissible, is by no means the only one which is intellectually tenable; and it is open to any one who finds intrinsic difficulties in the view in question to account for the existence of the narratives of the resurrection, with complete intellectual honesty, upon any one of a number of alternative theories. This means that it is impossible for history, regarded narrowly as "a science of evidence," to " prove" the resurrection of our Lord, either in the orthodox sense or in any other. It is equally impossible for a "science of evidence," as such, to disprove it.

Nor can the historian, when all is said, be content with the rôle of a mere annalist and critic of evidence. The idea of history 
which such a conception would imply is altogether too limited in its range. Rather must it be the historian's aim to arrive at such an intellectual construction of the past as shall be not merely a chronicle but an interpretation of events - a rationale of history in which causes are traced and sequences explained; and this means, in the present context, that the historian, quite apart from any theological beliefs or disbeliefs which he may entertain, is under the obligation of postulating, as lying behind the origins of Christianity, a cause or causes which shall be reasonably adequate, in his judgment, to account for the developments which have ensued from them. It is not enough to explain how the narratives of the resurrection may conceivably have come into existence and assumed their present form. What is needed is a reasonable explanation of the conviction of the Apostolic band that the Lord was risen, and of the course of Christian history as determined by that conviction. 
These preliminary considerations being disposed of, it may perhaps be of value to approach the subject from another point of view ; that is to say, from the point of view of the general context of the resurrection in the scheme of Christian doctrine. The Apostles' Creed, besides containing the statement "the third day $\mathrm{He}$ rose again from the dead," contains also the profession, "I believe in . . . the resurrection of the body." The resurrection of Christ has from the first been regarded as the type and pledge of an ultimate resurrection of the faithful, or indeed of all men universally. "As in Adam all die, even so in Christ shall all be made alive." With regard to the nature, however, of this latter resurrection, Christian thought has by no means been unanimous. The earliest Greek creeds profess a belief in the "resurrection

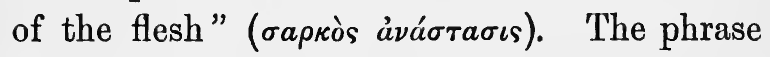
is not in itself biblical; and its exact meaning in this particular connexion is not absolutely clear. It appears to have been 
originally intended as a strong assertion of the reality of the resurrection, understood as implying the persistence in the life to come of the whole man, and not merely of a part of him. It is a controversial expression, directed against those who held the human body to be in itself essentially unspiritual, and regarded "the flesh" as a burden, from which "the spirit" must seek deliverance. This idea goes back to the Pythagorean conception of the body $(\sigma \hat{\omega} \mu a)$ as the tomb $(\sigma \hat{\eta} \mu a)$ of the soul-a doctrine which is found in the Book of Wisdom. ${ }^{1}$ Now, though the psychological basis of this theory is found also in St. Paul, ${ }^{2}$ yet the Church repudiated the idea of any ultimate metaphysical dualism between matter and spirit, and held to the Gospel of the Resurrection as implying a thoroughgoing triumph over the fact of

1 Wisdom ix. 15. "For the corruptible body weigheth down the soul, and the earthy tabernacle oppresseth the much-pondering mind." Cf. also Plato, Phaedo, $81 \mathrm{c.}$

22 Cor. v. 4. "For indeed we that are in this tabernacle do groan, being burdened." Cf. also the reference in the Prayer Book Burial Service to the "souls of the faithful, after they are delivered from the burden of the flesh," as being "in joy and felicity." 


\section{RESURRECTION \& THE LIFE 63}

death, such as was not satisfied by any form of words which appeared to suggest the survival of man hereafter only as a mere attenuated phantom of his former self. ${ }^{1}$ We find St. Ignatius of Antioch (circa A.D. 110) arguing against those who interpreted the resurrection of our Lord as a case of disembodied survival, asserting that $\mathrm{He}$ had risen "in the flesh," and quoting from some apocryphal source ${ }^{2}$ a passage in which the risen Lord is represented as saying, "Touch $\mathrm{Me}$, feel $\mathrm{Me}$, and see that I am not an incorporeal spirit." It would seem, therefore, that the motive underlying the insistence of early Greek writers upon the resurrection of the "flesh" is the desire to assert a survival or "resurrection" of man in the full reality and completeness of his individual personal life. In an age which regarded man as a being

1 So also St. Paul, in the passage already quoted, though regarding as a burden the body of this present flesh, is hostile to the idea of disembodiment. See below, p. 71 .

2 Ignat. Ad Smyrn. 3. According to Jerome (De Vir. Ill. 2-3) the source of the quotation was the "Gospel according to the Hebrews," translated by him into Latin. Lightfoot, however, doubts this, and thinks the saying came from the lost "Teaching of Peter." The view that the words are simply an inaccurate reminiscence of Luke xxiv. 39 is less probable. 
compounded of three elements ${ }^{1}$ - body, soul, and spirit-this meant the assertion of a survival of the "body," equally with that of the "spirit" and the "soul," and no hesitation was at first felt about the introduction, originally no doubt controversial, of the term "flesh."

It is claimed, moreover, by some theologians, that the associations of the term "flesh" were in this connexion not necessarily materialistic. Thus, for example, in St. John's phrase "The Word became flesh," what is meant is that the Word was expressed in terms of a genuinely human life, mediated by " the flesh." So with regard to the "resurrection of the flesh" it has been urged that, though the word "flesh" no doubt takes man primarily on his physical side, yet what it essentially means is just the man, as expressed here and now through the elements of this material earth : it is intended

1 The tripartite conception of human nature survives to-day only in the language of theologians. Our ordinary thought is dualistic; we contrast the "body" (i.e. the physical organism) with the "soul," "spirit," or " ego" (i.e. the personality embodied): but we do not-unless with conscious reference to the thought of the New Testamentdistinguish between the "spirit" and the "soul." 
to assert the doctrine that man, as he enters into "the life of the world to come," is the same man who expressed himself here and now through the flesh, the very man whose experiences in the flesh abide for ever, and who carries over into his new life all that he has here shown himself to be in the flesh. The essential point of the resurrection, according to this view, is the identity of the man whom the flesh had embodied and expressed with the man who inherits the Kingdom of Heaven : and it is this conception, so it is maintained, which the assertion of the resurrection of the flesh was designed to convey.

Whatever may be thought of this contention, it is undeniable that the phrase "resurrection of the flesh" inevitably lay open to materialistic misconstruction: and it is interesting to notice that in Eastern Christendom the form of expression came to be modified. All known Eastern Creeds from Constantinople onwards ${ }^{1}$ substitute the phrase

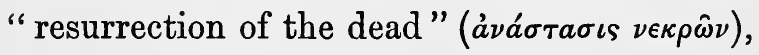

1 A.D. 381. The statement in the text is made on the authority of Dr. Hort. See also H. B. Swete, The Apostles' Creed, p. 97. 


\section{DOGMA, FACT \& EXPERIENCE}

the change being apparently due to the influence of the writings of Origen, ${ }^{1}$ who was led by a consideration of St. Paul's words in 1 Cor. xv. 37 ("Thou sowest not that body that shall be") to repudiate the idea of a literal resuscitation of the corpse. In the West Origen's views carried little weight : and indeed the prejudice against his doctrine militated against a proper understanding of St. Paul. The phrase "resurrection of the flesh" (carnis resurrectio) appears in all extant forms of the Apostles' Creed-the baptismal symbol of the West: and in Rufinus' version of the creed of his native place (Aquileia) we even have "resurrection of this flesh" (huius carnis resurrectio). " "Resurrection of the body" in the current English version of the Apostles' Creed is either a mistranslation or an intentional modification of the original, the correct rendering "resurrection of the flesh " occurring in the Prayer Book only in the interrogative version of the Creed, as it appears in the Baptismal Office.

The associations of the word $\sigma \grave{a} \rho \xi$ may, as

$$
1 \text { A.D. 185-254. }
$$

2 Rufinus, Comm. in Symb. xliii. Rufinus died in A.D. 410. 


\section{RESURRECTION \& THE LIFE 67}

we have seen, be disputable: but with regard to the Latin caro it is certainly difficult not to think that the assertion in Western Christendom of belief in "the resurrection of the flesh" was intended historically to mean what the terms prima facie suggest, viz. a resuscitation of the corpse. That has in fact all along been the popular view in the West, and it is shared by the most representative Western theologians. Thus Tertullian ${ }^{1}$ writes: "The flesh accordingly shall rise, and that, too, the actual flesh in its totality and in its integrity": ${ }^{2}$ St. Jerome ${ }^{3}$ declaims bitterly against the Origenists, who substitute "resurrection of the body" for "resurrection of the flesh" : ${ }^{4}$ and St. Augustine, ${ }^{5}$ though in his $D e$ fide et symbolo he deprecates the application of the term "flesh" to the "spiritual bodies" of the risen saints hereafter, ${ }^{6}$ declares in his

1 A.D. 160-240.

2 Resurget igitur caro et quidem omnis et quidem ipsa et quidem integra (Tert. De res. Carn. lxiii.).

3 Born about the middle of the fourth century : died A.D. 420 .

4 Hieron. Ep. 1xv. (ad Pammach. et Ocean.).

5 A.D. 354-430.

6 Non iam caro erit et sanguis . . . nulla caro, sed corpora simplicia et lucida quae adpellat Apostolus spiritualia (Aug. De fide et symb: x.). 
Retractations that the passage in question, which was written before he became a Bishop ("I wrote it," he says, " as a presbyter"), must not be so understood as to imply " that the earthly body such as we have it now is changed by the resurrection into a celestial body in such a way that these limbs and the substance of the flesh shall cease to be." 1 The analogy of the Lord's risen body, he thinks, forbids such a view. "Later Latin writers followed Augustine, the only important exception being the independent thinker of the ninth century, Johannes Scotus Erigena, whose philosophical mind rebelled against materialistic interpretations of the faith." ${ }^{2}$

The last half-century has witnessed a widespread revolt against the western and mediaeval view of the resurrection. The ruling influence has been that of Bishop Westcott, who, reverting to the Origenist conception attacked by St. Jerome, elaborated a doctrine which-although in itself a departure from Western tradition, and one, too, which may fairly be said to involve a formal contradiction of the letter of the Apostles' Creed

1 Aug. Retract. i. 17. 2 Swete, op. cit. p. 96. 


\section{RESURRECTION \& THE LIFE 69}

in its Latin form-is now generally received and admitted as orthodox. ${ }^{1}$

According to this view the flesh, which sees corruption, is not raised. "Flesh and blood," as St. Paul put it, " cannot inherit the Kingdom of God, neither doth corruption inherit incorruption." ${ }^{2}$ Rather we are to think of body as the manifestation and organ of spirit. "We are not these changing bodies which we bear," and the revelation of the Risen Christ in the Gospels is held to suggest the idea of a changed embodiment hereafter, which shall be the appropriate vehicle and expression, in relation to that new order of existence, of the same personal and individual life which is expressed here and now by the body of flesh and blood.

1 Westcott, The Historic Faith, and more fully in The Gospel of the Resurrection.

21 Cor. xv. 50. It is sometimes suggested that the meaning of "flesh and blood" in this passage is "humanity apart from grace." Man as he is in himself, in other words, cannot inherit the Kingdom: only man as he is transfigured by the Spirit can inherit it. But the words which follow ("neither doth corruption inherit incorruption") appear to be decisive in favour of the interpretation in the text. 


\section{III}

St. Paul's conception of the resurrection of the faithful, which we may next proceed to consider, is expressed for the most part in the imaginative language of a glowing rhetoric which eludes precision and affords no direct or conclusive answer to our modern questionings. To ask, indeed, "How are the dead raised, and with what manner of body do they come?" is, he cries, to ask a foolish question. In God's universe there are bodies of very different kinds, bodies celestial and bodies terrestrial, sun and moon and stars, differing each from each in glory. "So also," he proceeds, " is the resurrection of the dead. It is sown in corruption; it is raised in incorruption : it is sown in dishonour; it is raised in glory: it is sown in weakness; it is raised in power: it is sown a 'natural' body ; it is raised a 'spiritual' body." 1 Here the emphasis appears to be laid upon the unlikeness and discontinuity between the new body and the old. Similarly in 2 Cor. v. 1 sqq., he speaks of the new body as a "building

11 Cor. xv. 35 sqq. 
from God, a house not made with hands, eternal in the heavens," with which he is eager to be "clothed upon." He shrinks from the idea of disembodied existence, and for this reason he would fain be alive when the Lord returns, that he may receive the new embodiment without losing the old, and that thus " what is mortal may be swallowed up of life." 1

On the other hand, his comparison of the plant which springs up in a new form from the seed which is buried in the earth ( 1 Cor. xv. $36 s q q$.$) , appears to assert a continuity of$

1 It is plain that St. Paul in 2 Cor. v. $1 s q q .$, regards the new body as pre-existent in the heavens and already awaiting him. When is he to receive it? It has commonly been held that he expects to be "clothed upon" at death, and for that reason can look forward with equanimity to the dissolution of his "earthly house," being assured that he will not in any event be "found naked." A more accurate exegesis suggests rather that the "habitation which is from heaven" is regarded as reserved until the Parousia of the Lord : and that in St. Paul's view an intermediate state of " nakedness" was inevitable unless the Parousia happened in his lifetime and so enabled him "not to get this frame off but to put on the other over it" (v. 4). This he would greatly prefer, though he is ready if need be to be "absent from the body," provided he may be "present with the Lord": and if death involve closer union with Christ, then he prefers death. See Menzies' Commentary, ad loc. 


\section{DOGMA, FACT \& EXPERIENCE}

principle between the old body and the new, and in Romans viii. 11 he declares that "He that raised up Christ Jesus from the dead shall quicken also your mortal bodies through His Spirit that dwelleth in you." Plainly the Apostle's conception of the resurrection of the faithful was modelled closely upon his conception of the resurrection of Christ, and this in its turn included, to his mind, the resuscitation of the Lord's dead body from the grave, though in a changed form. Yet when the question arises of the extension of this analogy to the case of the resurrection of the departed faithful, whose flesh had "seen corruption," his thought appears to fluctuate, and it is impossible to derive from his writings a completely consistent system; his instinct, however, is not in this latter case to assert a resuscitation of the flesh, but to think rather of God at the Parousia as clothing the spirit with a new embodiment, physically discontinuous with the old, and analogous to the changed embodiment wherewith those who lived to see the Lord return were to be "clothed upon," according to the thought of 2 Cor. v. 4. 


\section{RESURRECTION \& THE LIFE 73}

Now, in our own time an increasing number of people feel themselves precluded, for a variety of reasons, from accepting so naïvely realistic a construction of the "Advent Hope" - the belief in the coming of Christ to judgment and the consummation of His kingdom in triumph-as St. Paul when he wrote to the Corinthians appears to have entertained. We have learnt to recognize more fully the inevitability of symbolism in religion : and in particular, as the Bishop of Oxford has recently pointed out," it is felt that "the Biblical descriptions of 'the day of the Lord' both in the Old Testament and in the New are highly figurative." The principle is one which is capable of far-reaching application with regard to the whole scheme of the traditional eschatology-the conceptions, for example, of Heaven, Hell, the Intermediate State or Purgatory, the Day of Judgment and the General Resurrection. It must mean that we think in general of "the life of the world to come" with a fuller realization of the truth that in respect of all matters which lie outside the range of

1 In an article on "The Place of Symbolism in Religion," in the Constructive Quarterly, March 1914. 


\section{DOGMA, FACT \& EXPERIENCE}

our present human experience "we see through a glass darkly": and it must follow that anything like detailed dogmatism with regard to the manner of that resurrection for which the Christian looks "in sure and certain hope" is out of place. The Last Trump, the Rapture of the Saints, the opened graves, the Great Assize - these are but imaginative and pictorial figures of a reality which evades our present knowledge : and while it is one thing to affirm the truth of the spiritual values which the dogma of the resurrection enshrines, it is another to press with literal realism a language which is inevitably that of symbol. It is sufficient if we assert that to the Christian "Death is swallowed up in victory," and that we shall live hereafter-ourselves in our whole being -in the fulness of personal life.

Many persons who may be willing to admit that this is a true account of how in point of fact they do actually think upon this subject, will nevertheless be disposed to ask whether a view which refuses to assert the resurrection of the flesh is not really tantamount to a frank abandonment of the Christian dogma of the resurrection, and the substitution 
for it of a belief in the immortality of the soul ; and it must be admitted that " resurrection" is hardly in itself the most natural word by which to express a belief which avowedly does not involve any rising again of the buried corpse. If it be granted, however, that in speaking of the nature of the life to come we are driven to use the language of symbolism, which suggests more than it can express, then it must be pointed out that as regards what is suggested by the symbolism not a little may turn upon the associations of the particular imagery employed. The conception of disembodied existence is as remote from our present experience as is the conception of resurrection. As modes of thought under which to envisage the nature of the life to come both are equally symbolic. Whereas, however, the idea of a disembodied existence is instinct for the imagination with the associations of the classical Hades and the Hebrew Sheol, and suggests the conception of an attenuated and shadowy hereafter, of the "sheeted dead" that "squeak and gibber," the "thin ghosts flitting bodiless" in some Limbo of an underworld, or the pathetic 


\section{DOGMA, FACT \& EXPERIENCE}

futilities of the modern spiritualistic séance, the Christian concept of resurrection connotes by contrast a life fuller and more glorious than the life of earth, an existence richer and more real than that which we know here. "To depart hence is not to perish ; it is to survive the perishing of all that was less real about us, the fading of all the shadows with which our life was darkened." " We have only to compare, for example, the Homeric picture of the state of the dead with the hope of the resurrection as reflected in the New Testament writings in order to perceive the difference which Christ has made. The spirit of the dead man in the Homeric conception is a mere semblance or wraith of the man himself; "the living heart is not in it." "The real self (aùós) is either the corpse left on earth (Iliad, i. 4) or the man as he formerly lived (Odyss. xi. 574)." ${ }^{2}$ Achilles' ghost is made to declare that he would rather be a poor man's serf upon earth than bear rule as king over all the departed in the world below. ${ }^{3}$

1 From the Funeral Sermon in Sir Henry Newbolt's novel, The Old Country.

2 Jebb, Homer, p. 72.

3 Odyss. xi. 489-491. 


\section{RESURRECTION \& THE LIFE 77}

How different from St. Paul's " $O$ death, where is thy sting? O grave, where is thy victory?" or from the words which speak of "Christ Jesus, who abolished death, and brought life and immortality to light through the Gospel "!

It is this difference of outlook which the doctrine of resurrection enshrines and conserves : and, moreover, if it be true that the transfigured life of man's spirit involves for its completeness some material vehicle or organ of self-expression, analogous to the present physical frame; if "body" may in fact be defined as "the medium of distinction and of manifestation and communion between spirit and spirit," ${ }^{2}$ then we must say that the life hereafter will be an embodied and not a disembodied life. As to how or in what sense this will be so we are not here and now in a position to know. We may well be content to say with St. Paul, "God giveth it a body as it has pleased Him, and to each seed a body of its own," a body, that is to

11 Cor. xv. 55 ; 2 Tim. i. 10.

2 I borrow the definition from a paper on "The Risen Body," by the Rev. Wilfrid Richmond. 


\section{DOGMA, FACT \& EXPERIENCE}

say, which shall express-which shall, in fact, embody-all that the individual is or has come to be: so that "the deeds done in the body" here upon earth shall not be irrelevant to the life of the world to come, but shall determine and constitute the specific character of " the body that shall be." It is this conception which as applied to the case of our Lord is expressed poetically in the words of the hymn-

Those dear tokens of His passion

Still His dazzling body wears,

and which as applied to the case of Christians lends its specific force and point to the appeal of St. Paul to the Corinthians not to defile their bodies, which are the temples of the Holy Ghost and as such are to be "raised up" hereafter. ${ }^{1}$

St. Paul distinguishes " the body that shall be" from the body that now is by describing

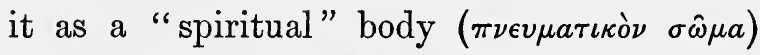
or embodiment of the spirit, as contrasted

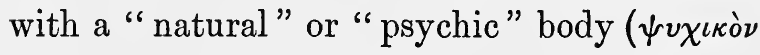
$\sigma \hat{\omega} \mu a)$, the embodiment of the "soul" or $\psi v \chi \eta^{\prime}$, i.e., the principle of the life of man so far as

11 Cor. vi. 13-20. 
he is an animal. This antithesis is not in itself an antithesis based upon the respective physical constitutions of the two embodiments. It has, for example, nothing to do with the popular antithesis between "spirit" and "matter." No doubt St. Paul expected the "spiritual body" to be different from the present "psychic" body, but he does not say that he expected it to be any less material. "Spirit" is not "matter worn to an extreme thinness"; nor does "spiritual body" mean an immaterial body or a body composed of "spirit" - as though the latter were a kind of stuff, any more than "psychic body" means a body composed of $\psi v \chi \grave{\eta}$ or " soul." To speak of an "immaterial body" is, in fact, strictly speaking, to talk nonsense, even though it does not necessarily follow that all bodies must be composed of matter as the physicist understands that term. St. Paul held that our Lord's body after the resurrection was changed: are we to hold that it was more "spiritual" than before? Ought we not rather to say that in virtue of our Lord's perfection and sinlessness His body was always the perfect instrument of His spirit: 


\section{DOGMA, FACT \& EXPERIENCE}

and that even apart from the case of our Lord, the body of a spiritually-minded and saintly Christian is more "spiritual" and less "psychic" (though not less material) than the body of a debauchee, because more subdued and controlled to spiritual ends? Of the nature of the "spiritual" body which is to be ours hereafter the Apostle's language affords, as a matter of fact, no indication whatever : that, it is implied, is a secret hid in God's keeping"Behold, I show you a mystery": ${ }^{1}$ and by a "mystery" St. Paul means a divine secret, hid until now, but destined shortly to be revealed. What he is trying to express by his phrase "a spiritual body," and what in fact he does express, is simply that the future embodiment, whatever its nature, will be one which adequately expresses and mediates the life of the spirit, in a fashion analogous to that in which the present physical frame may be regarded as an adequate expression and vehicle of the life of sense. 
"The souls of the righteous are in the hand of God." "I am the God of Abraham, and the God of Isaac, and the God of Jacob." "The eternal God is thy dwelling-place : and underneath are the everlasting arms." The ultimate basis of the Christian doctrine of life is the faithfulness of God and the preciousness in the sight of God of every individual soul. It is this which assures us that nothing shall be lost of that which constituted the living person what he was-even though "we are not these changing bodies which we bear." Thus it is that for the Christian "to depart" is to be "with Christ, which is far better": and of those who are fallen asleep in Christ we are constrained to believe that they have passed to "a much fuller and more immediate apprehension of God than is possible on the earth, that they are, to speak in spatial metaphors, nearer to God, with Christ." I Yet we cannot but believe that this fuller apprehension, this nearness

1 Edwyn Bevan, "The Invocation of Saints," in the Constructive Quarterly, December 1913. 


\section{DOGMA, FACT \& EXPERIENCE}

to God, is in the case of the departed, equally with that of the living, a matter of gradual attainment-that is the underlying truth of the doctrine of Purgatory. The idea of Purgatory-that is to say, of a progressive elimination after death of whatever of sinfulness persists within the soul, and a correspondingly progressive growth in purity and holiness-is an almost inevitable element in any considered doctrine of the life to come; and it is reasonable to suppose that such progressive "growth in grace" is achieved hereafter, as it is here upon earth, partly through the discipline of effort and of suffering.

The doctrine of Purgatory, like the doctrines of Heaven and of Hell, has no doubt often been taught in crude and repellent forms. In mediaeval times Purgatory was regarded, like Hell, as a "place" in which souls were plunged into literal or quasi-literal fire, the difference being that whereas the fires of Hell were eternal, those of Purgatory were limited in duration, and the endurance of them was a "temporal penalty" which the sinner paid to the Divine Justice by way of "satisfaction" for the guilt of forgiven sins. 


\section{RESURRECTION \& THE LIFE 83}

We may reject the profit-and-loss conception of man's relation to his Maker here implied, together with the retributive theory of punishment according to which a specific amount of pain is inexorably "due," and must be rendered as satisfaction for a specific degree of guilt. But the crudity in this respect of the mediaeval conception of Purgatory ought not to be allowed to have the effect of obscuring the essential truth of the purgatorial idea. ${ }^{1}$

The question may at this point be raised as to whether we ought to think of the souls of the departed, pending a future day of general resurrection, as existing in the disembodied condition which St. Paul described as that of being "found naked," or whether we ought not rather to regard them as having

1 The chief defect in the traditional conception of Purgatory has been its failure to recognize the manner in which not only pain or sorrow, but also joy may minister to spiritual advance. It is true that in Newman's Dream of Gerontius the happiness of Gerontius' soul in Purgatory is emphasized, and it is represented as suffering only as the result of inability to bear the immediate vision of the "keen sanctity " of God's infinite and holy love. The atmosphere is none the less predominatingly sombre, and a truer psychology would recognize, side by side with the deepening of penitence, a deepening joy in God's service. 
been already in some sense "clothed upon" with their "habitation which is from heaven." On the one hand, it is undeniable that the traditional eschatology of the Church, as it came to be systematized in patristic and mediaeval times, did postulate a period of disembodied existence as intervening between the death of the individual and the final consummation. Not only were the souls in Purgatory regarded as disembodied, but those also who were classed as "saints" in the distinctive sense of that word, and who were regarded as being already "in Heaven," and as having already in some measure attained to the "beatific vision" of God, were nevertheless not thought of as having entered upon their resurrection life, but as destined still to "rise" upon the last great Day. We have seen, too, that St. Paul's teaching is probably in line with this conception, and that the interpretation of his words which makes him expect the "clothing upon" with the "habitation which is from heaven" to take place at the moment of death is mistaken.

On the other hand, as the figurative nature of eschatological language is more and more 


\section{RESURRECTION \& THE LIFE 85}

widely realized, it is increasingly felt to be difficult to take the expectation of a single great Day of General Resurrection altogether au pied de la lettre; and the philosophical argument, if we are to press it-the argument that a life of the human spirit without body is not properly conceivable, that a "body" in some sense is the indispensable vehicle and medium of the manifestation and communion of spirits, so that soul and body ought to be regarded as being "not so much two things as two different aspects of the same thing "1-would seem to suggest rather the idea of a reembodiment of the spirit immediately at death.

The point is one with regard to which we may well be content to remain agnostic: but we cannot in any case be content to regard the state of those departed as one of mere "deadness" and quiescence. The New Testament writers speak of them, indeed, by a natural metaphor, as "sleeping" ${ }^{2}$ but the

1 The Rev. Wilfrid Richmond, in the unpublished paper already quoted.

21 Thess. iv. 13-15, John xi. 11 ; cf. also the Christian

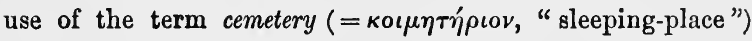
to denote a place of burial. 
implications of the metaphor are not to be pressed, for "God is not the God of the dead, but of the living": and we must think rather of the condition of those who are "with Christ" as one of purification and spiritual advance, of more and more perfect participation in the Mind and Will of Him who is their Lord-a Mind and Will which, as all Christians believe, are directed Godwards for the good of men in intercessory prayer for the Church, whether as "militant here in earth" or as expectant in the world beyond." In the communion of saints living and "dead" are knit together: there is an intercourse of mutual intercession: and doubtless to those who have passed beyond the veil of sense there is given increasingly

A life that bears immortal fruit

In those great offices that suit

The full-grown energies of heaven.

Yet the Christian salvation is a social salvation-we speak advisedly of the communion of saints: and so long as their

1 Cf. Mr. Edwyn Bevan's remarks in the article already quoted. 


\section{RESURRECTION \& THE LIFE 87}

brethren are still "militant here in earth," the condition of those departed must continue to be one of expectation, directed towards a consummation yet to come. "They without us shall not be made perfect." 'The complete fruition of the life of God, we are tempted to say, and the ultimate realization of the Divine Kingdom, are impossible for any, apart from the attainment of them by all. The loss of a single soul is the detriment alike of God and of His Church (the inference from this to the doctrine known as universalism is tempting, but need not necessarily be drawn), and the bliss of the redeemed will be incomplete until all God's elect have been gathered in. May we not say that this is the truth which the traditional eschatology is expressing "in a figure" when it interposes an intermediate "state of waiting" between the death of the individual and the general consummation?

Supposing it to be granted that the foregoing pages represent not unfairly the manner in which we interpret the affirmation in the 
Creed of belief in the resurrection of the body, we may next proceed to consider how far the religious values of the Easter Gospel compel us to assert an historical resurrection of our Lord Jesus Christ in a sense which goes beyond that in which we look for a resurrection of the faithful generally. If we are not in our own case to look for a resurrection of the flesh, in the ordinary prima facie meaning of those words, it is clear that, in so far forth as our Lord's resurrection is regarded as a type and pledge of our own, the most essential and vital of the spiritual issues at stake are adequately safeguarded by any view which involves the assertion of a real triumph on the part of the crucified Lord over the fact of death, and His manifestation to the disciples as veritably alive after His Passion and personally in communion with them. ${ }^{1}$ It is sufficient, thus far, to believe in the resurrection of our Lord in a sense identical with that in which we believe in our own. Are there

1 Cf. the Rev. B. H. Streeter: "The appearances ... can only be styled 'visions,' if we mean by vision something directly caused by the Lord Himself veritably alive and personally in communion with them" (Foundations, p. 136). 


\section{RESURRECTION \& THE LIFE 89}

any further spiritual issues involved, which are in such wise peculiar to the special case of our Lord, as to render incomplete the analogy drawn by St. Paul between His resurrection and ours? Apart from the question of evidence, is it essential to affirm in His case, though not in our own, a resurrection of the flesh?

It is commonly held that further spiritual issues are at stake, and that the analogy between the resurrection of the Lord and the resurrection of the faithful is incomplete. Arguments of very varying value are adduced in support of this contention. It is urged, for example, that humanity apart from the body is maimed and incomplete, and that a rising again which did not involve the resurrection of the flesh of Christ would be a resurrection of something less than a completely human Christ. Christ's body must rise, as well as His soul and His spirit, that the whole Christ may triumph over death. But the argument, thus stated in terms of the tripartite theory of human nature, fails to carry conviction. One is tempted to echo the words of the Apostle, and to ask, "Is Christ divided?" If 
we, who are Christ's brethren according to the flesh, "are not these changing bodies which we bear," if the resuscitation of the flesh is not in our case essential to the completeness of our being hereafter, why should the facts be otherwise with Him? Why should there be any intrinsic necessity in the one case more than in the other for the body of the resurrection to be physically continuous with the body of the life as lived upon earth? That the Christ has not ceased to be incarnate : that He lives still in the fulness of His human personality : that His being is qualified for all time by the experiences of His human life and Passion and by " the deeds done in the body" here upon earth: this indeed it is essential to assert. But the persistence in this sense of the Incarnation as an eternal fact is not necessarily dependent upon a physical continuity of material embodiment. It is sufficient that the Christ is to all eternity fully and completely man. ${ }^{1}$

1 Etymologically the term "incarnation" is the equivalent

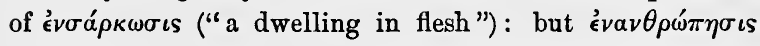
("a dwelling in manhood ")—-the word used by St. Athanasius in his famous treatise On the Incarnation-represents more accurately its theological value. 


\section{RESURRECTION \& THE LIFE 91}

It is urged, however, in the second place, that the resurrection of the flesh of Christ is essential to the Catholic doctrine of the sacraments. "It is the glorified humanity of the Lord," writes Dr. Goudge," "into which we are baptized; it is that same glorified humanity which is our spiritual food in the Holy Eucharist; it is that glorified humanity, once more, which is the promise of our own future glorification, and of the ultimate transformation of the world itself." If for the abstract phrase "glorified humanity of the Lord" we may be permitted to substitute "Christ Himself, glorious and human," there is nothing in this statement to which it is necessary to take exception. But there is also nothing in it which is in itself incompatible with a conception of the Lord's resurrection as identical in its mode with our own.

The point will become clearer if we consider for a moment the significance of the phrase "body of Christ" as used in the New Testament. The terms are employed in various contexts to denote three entities-the physical frame which Christ had from Mary,

1 Church Quarterly Review, January 1913, pp. 282-283. 
92 DOGMA, FACT \& EXPERIENCE

the Church, and the Eucharistic Bread-which are regarded as being in some sense mystically identical. If, however, we ask ourselves what it is that constitutes their identity, we are surely constrained to find the answer to our question not in the conception of a quasiphysical unity of substance as underlying them, but in the recognition that it is one and the same Christ who is embodied in all three. The identity, in other words, is not an identity of embodiment, but an identity of the Person embodied.

No doubt it has been traditional in Catholic theology both to think of Christ's body, risen and ascended into heaven, as in some sense physically continuous with the body of His earthly life, and also to conceive of it as being present in Holy Communion in a supersensuous manner beneath the outward and visible form or species of bread. Thus the Bishop of Zanzibar, criticizing the teaching of Canon Streeter in language of which the rhetorical vigour is purchased, surely, at the cost of a certain crudity in the thought, complains that it involves the doctrine that the Lord's body, "so far from being received in 
Holy Communion, is mingled with the dust of Palestine" : ${ }^{1}$ and St. Thomas Aquinas goes so far as to raise the question why the "accidents" of bread should be suffered to remain at all in the transubstantiated Host, and decides that it was necessary to veil the "substance" of Christ's body from the cognizance of sense, in order to overcome the natural repugnance of man to eat human flesh. ${ }^{2}$ The doctrine of concomitance, according to which "the whole Christ is in this sacrament," and $\mathrm{He}$ is " whole under each species of the sacrament," together with such statements as that He is eaten "only after an heavenly and spiritual manner," ${ }^{3}$ may perhaps save such a theory from the charge of cannibalism: but the whole difficulty is surely unnecessary. Is it not sufficient to say simply that we are baptized into the Church, in which the living Christ is embodied through the Spirit, and which for that reason and in that sense may rightly be described as His Body: that the Christ who is embodied in the Church is the same Christ

1 Ecclesia Anglicana, p. 22.

2 Summa Theologiae, III. 1xxv. 5.

3 Article XXVIII. of the Church of England. 


\section{DOGMA, FACT \& EXPERIENCE}

who suffered and died, and who also manifested Himself alive after His Passion: that we feed spiritually upon Christ in the sacrament of His institution, and the Bread of the Eucharist is the Body of Christ because it embodies and mediates Christ Himself-the same Christ who was once expressed upon earth through the flesh-to be the food of our souls : that the Wine of the Eucharist is His Blood, because it is the vehicle and medium of His life, which was given for the life of the world? Is there anything in all this to render necessary of itself a belief in the resurrection of His physical flesh?

It is true, indeed, that the word "flesh" $(\sigma a ́ \rho \xi)$ occurs in St. John vi. 51 sqq., where our Lord is represented as saying, "Except ye eat the flesh of the Son of Man and drink His blood, ye have no life in yourselves": and in spite of the various attempts which have been made to interpret the passage differently, we should agree that the discourse in which these words occur is a reflexion of early Eucharistic doctrine. But the words surely stand for the living Christ Himself, who lived humanly in the flesh, and who shed 


\section{RESURRECTION \& THE LIFE 95}

His blood for men. A literal interpretation of them is excluded by the words which follow in verse 63 of the same chapter: "It is the spirit that giveth life: the flesh" (i.e. the flesh as such) "profiteth nothing. The sayings which I have spoken unto you are spirit and are life" $:^{1}$ in other words, "You are not to understand My sayings in a carnal sense : by the expressions 'My flesh' and 'My blood,' I mean 'My spirit' and 'My life': and it is these which constitute the inner reality of the Eucharist." It is difficult, therefore, to feel that the case for a physical continuity and identity between the body of Christ in His Passion and His body in the Eucharist has been made out.

There are other arguments, however, which, if their validity be granted, must be acknowledged to have greater significance. Thus, it

1 The use of the term $\rho$ ' $\mu a \tau a$ (= "words" or "expressions") rather than $\lambda o ́$ ' $о \iota$ (="sayings") in St. John vi. 63 almost suggests the translation, "The terms which I have used in speaking to you denote 'spirit' and 'life.'" 
is maintained that the Resurrection of Christ is not simply a type and pledge of the resurrection of the faithful, but a redemptive act of God, as concrete and "external" as were the Crucifixion, Death, and Burial : a supreme exhibition of Divine grace and power: the mystical basis of a resurrection of the faithful to newness of life here and now, as the Crucifixion is the mystical basis of their death to sin : a raising and exaltation of humanity to the throne of God, on the part of a Divine Redeemer who came from above precisely in order that He might lift up our nature into union with Himself. Conceptions of this kind are expressed inevitably in terms of language which is largely metaphorical: and it is sometimes difficult to feel confident that more is not being based upon a metaphor than it will really bear. But it is felt that there is a certain unsatisfactoriness in the idea of the risen Christ leaving behind, as it were, His earthly frame as a butterfly leaves behind its chrysalis, casting it from Him (to put it crudely) as a thing for which God had no further use. In forcible contrast with this idea might be quoted the words once used by a 
speaker in my hearing: "Our Lord Jesus Christ took to heaven the body of a working man."

We are driven back, in short, upon the demand of the religious mind and heart for miracle; and especially for such a demonstration, in this crucial instance, of the power and goodness of God, as shall avail to overcome any thought of an ultimate dualism between the physical order, with its seeming cruelties and its apparently inevitable laws, and the moral demands of righteousness.

\section{VII}

It is historically clear that it was the manifestation of the risen Lord by many "evident tokens" to the disciples which in their eyes vindicated Him as Messiah, in spite of the immediate disaster of the crucifixion, and in vindicating Jesus, vindicated also the power and goodness of God. Nothing else, indeed, could possibly have availed to overcome for them "the scandal of the Cross,"

1 For an elaborate study of the psychology of the original followers of our Lord, in which this point is forcibly and clearly made, see the Rev. N. S. Talbot, The Mind of the Disciples, passim. 


\section{DOGMA, FACT \& EXPERIENCE}

or to lead them to see in it anything but the ruin of their hopes. It is historically evident, also, that the resurrection of Jesus in their conception of it involved also the resurrection of His flesh. The presuppositions of their Jewish faith rendered this all but inevitable, for the Jewish hope of a hereafter was not based, like that of the Greeks, on a belief in immortality, but on the doctrine of a resurrection at the coming of the Messiah. The literature of contemporary Apocalyptic is full of this conception, which assumes, indeed, various forms, and in some cases includes the idea of a transmutation of the bodies of the righteous into "garments of glory and beauty," but only upon the basis, even so, of an initial emptying of the graves. ${ }^{1}$ With a preconception of this kind the discovery that the tomb in which Christ's body had been laid was subsequently empty would plainly harmonize: so much so that the accounts of

1 Cf. Apocalypse of Baruch, xlix.-li.; Eth. Enoch, lxii. In two passages (Eth. Enoch, ciii. 3-4; Jubilees, xxiii. 31), there seems to be implied the idea of a "resurrection" of the spirit only; but the writings in question are in this particular quite unrepresentative of Jewish Apocalyptic Eschatology as a whole. 


\section{RESURRECTION \& THE LIFE 99}

the finding of the tomb empty have been rejected as unhistorical, on the assumption that the Apostles, being convinced that the Lord was risen, took for granted the emptiness of the tomb without troubling to verify it; and that the tale of the women's visit to the sepulchre on the first day of the week grew up subsequently as an apologetic myth which was devised by way of an answer to the difficulties raised by objectors in the course of controversy. The criticism, however, which would thus seek to eliminate the empty tomb is purely arbitrary and subjective, since the story is contained in our earliest Gospel narrative, that of St. Mark; being, in fact, in view of the breaking off of his authentic narrative at precisely that point, the only episode connected with the resurrection for which we are definitely able to allege his authority. The evidence for the emptiness of Christ's tomb is indeed precisely the same in kind and in amount as the evidence for His burial; and among those who reject the former Loisy is consistent in rejecting also the latter, and assuming that the body of Jesus was buried (or left unburied) by the 


\section{DOGMA, FACT \& EXPERIENCE}

Romans. ${ }^{1}$ But this is not to write history; it is to invent it: and if a priori considerations are to determine the matter, it may equally well be urged that apart from the confirmatory evidence of the empty tomb the visions alone would not have carried conviction to the disciples' minds. Certainly the character of their preaching would have been different if they had believed the Lord's body to be still in the tomb, and it is hardly credible that they should have left the tomb unvisited. The facts, whatever they may have been, with regard to the disposal of the Lord's body must quickly have become notorious in Jerusalem as soon as the disciples began to preach there; and the circumstance that the body was no longer in evidence was to the disciples themselves a "sign," upon the basis of which they felt sure of the truth and validity of their Gospel. Nay, it was very substance of that Gospel itself; in the story of "Jesus and the Resurrection" ${ }^{2}$ the entire content of the earliest Christian preaching was summed up.

1 Loisy, Les Évanyiles synoptiques, ii. pp. 696 sqq.

$\approx$ Acts xvii. 18. 


\section{VIII}

Now, it is quite true that no thoughtful teacher would in our own day dream of basing the truth of Christianity primarily upon the evidence for miracle. In this sense it is certainly true that the "sign" which convinced the disciples can be no immediate and indubitable sign for us. No one to-day would entertain for a moment the possibility of the idea that Jesus may have risen physically from the dead, unless he were already prepared or disposed upon other grounds to believe that Jesus was or may have been the Son of God. This means that it is simply untrue to aftirm that Christian belief to-day is built upon the empty tomb.

It by no means follows, however, that belief in the empty tomb, or in the physical resurrection of our Lord, may not be a corollary of fully articulated Christian faith. That is a wholly different question, and one which demands and merits serious and temperate discussion. It may reasonably be urged that the implications, for example, of such a view as 


\section{DOGMA, FACT \& EXPERIENCE}

that propounded by Canon Streeter," in which an acceptance of the empty tomb as an historical fact is combined with a tentative refusal to assert a resurrection of Christ's flesh, appear to the minds of many Christians to be even more difficult than the traditional affirmations.

The theory in question asserts (i.) that the disciples found the tomb empty; (ii.) that the Lord after His Passion manifested Himself to them alive: and it is admitted that the disciples themselves inferred that the emptiness of the tomb was due to the fact that the Lord's body had been raised, and that it was because His body had been raised that $\mathrm{He}$ was able to manifest Himself alive. A doubt is, however, suggested as to the necessity of these inferences. It is pointed out (i.) that since a resurrection of the flesh is not to be literally anticipated in the case of the faithful, it is conceivable that it may not have been necessary in the case of our Lord; (ii.) that the emptiness of the tomb may have been due to some cause not directly supernatural, and the secret of what actually happened to the physical body of Christ may be irrecover-

1 Foundations, pp. 127 sqq. 


\section{RESURRECTION \& THE LIFE 103}

ably lost. It is possible, therefore, that the interpretation which the disciples placed upon the facts may have been in part erroneous; and since it is probable that, apart from that interpretation, the facts would have failed to carry conviction to their minds, the possibility remains open that a partial error on their part may have played a part in the Divine process whereby they were convinced of the essential truth that Christ was risen and alive from the dead.

Now, since the thoughts of God are not as the thoughts of man, and the mind of man is incapable of entering fully into the mind of God, a divine revelation to mankind must no doubt of necessity involve some element of what is known as "accommodation." Just as a blind man may gain a better suggestion of the appearance of scarlet if he is told that it is "like the sound of a trumpet" than if he is simply informed that it is indescribable; so mankind may be permitted to think of God in ways which, though always inadequate, are yet the most adequate which are for the time being available. And just as a wise teacher will instruct his pupils in the rules 
first and only afterwards set them to learn the exceptions, notwithstanding the fact that until the latter are known the application of the former may mislead, so no doubt a like principle may be traced in the Divine education of mankind. There has been advance from the lower to the higher stages of knowledge, and men have been suffered in the process to make mistakes and to learn through the mistakes they made. There has been conveyance of spiritual truths under the forms of myth and allegory and symbol, and the forms have not always been clearly recognized for what they were. It were a rash judgment to deny the educational value of illusions; and it would be over-hasty to assume that God could not under any circumstances permit an illusory judgment to be the means of conveying a truth. The principle of accommodation being admitted, it is impossible to rule out a priori the theory that a mistaken inference with regard to a point of minor importance may have been among the means employed in God's providence to lead the disciples to a knowledge of the risen Lord.

Nevertheless, when all is said, the difficulty 
of Canon Streeter's view remains a real one. It is not necessary to call in question the general principle of accommodation in order to shrink from the admission of so violent an instance of its application as is implied in the idea of the playing off upon the minds of the disciples of a kind of providential trick, whereby they were led to believe in a resurrection of the flesh of Christ which had not actually, in point of fact, occurred. To this difficulty must be added a certain instinctive repugnance of Christian sentiment towards the idea of our Lord's flesh having "seen corruption "; and many persons who repudiate heartily the deistic conception of miracles as an arbitrary intervention $a b$ extra in the course of a "Nature" whose ordinary workings are regarded as automatic and mechanical, nevertheless see nothing impossible, upon a theistic view of the world, in the idea of a departure from the normal habitude of the Divine working in so far as such departure may have been essential in this particular instance (and, it may be, in others too) to the Divine purposes of revelation and grace. The mechanical uniformity of natural sequence is 


\section{DOGMA, FACT \& EXPERIENCE}

indeed broken upon such a riew; but the moral consistency of the Divine character, upon which the order of nature itself depends, is maintained.

Any view which ascribes a real uniqueness either to our Lord's resurrection or to our Lord's Person involves a "miracle" in some sense, inasmuch as whatever is regarded as sui generis thereby ceases to be explicable as an "instance" of a general "law"; and the Incarnation as a whole (as it has recently been pointed out with equal force and point ${ }^{1}$ ) is the central miracle of all-that "Miracle of Christianity" upon which everything else depends. If Christ be indeed a Divine Redeemer, the Word made flesh, who for us men and for our salvation came down from heaven, then His coming is indisputably an "intervention" of God upon the arena of the world's history. The question of the mode of His resurrection is subordinate to this; and for the choice and the ultimate decision, if it is necessary to choose and to decide, as between the view of Canon Streeter and the view, for

1 The Miracle of Christianity: an Open Letter to the Bishop of Oxford, by the Rev. Dr. J. F. Bethune-Baker. 
example, of Bishop Westcott, the Church can afford to wait.

IX

The difference between the two is in any case, as regards the spiritual issues involved, very much less than is commonly supposed. Both conserve a parallelism between the resurrection of Christ and the resurrection of Christians. Both are compatible with a Catholic doctrine of the sacraments. Both involve the affirmation of a miracle, in the sense of an historical event which was in some respects sui generis. And both justify the spiritual values of the Apostolic Gospel.

On the other hand it should be recognized that both equally involve a departure from the letter of the Apostles' Creed. Bishop Westcott and the modern orthodox, equally with Canon Streeter, refuse to affirm in regard to the resurrection of the faithful departed a resuscitation of the flesh, which the mediaeval orthodox asserted, and which the letter of the Apostles' Creed in its Latin form implies. ${ }^{1}$

1 Bishop Westcott himself claimed to assert the resurrection of the flesh : but it is not unfair to say that the terms 


\section{DOGMA, FACT \& EXPERIENCE}

Bishop Westcott's conception, moreover, of the resurrection of our Lord as involving a transmutation or "glorification" of His body, of such a kind that subsequently to His rising He was normally invisible and intangible, and only rendered Himself otherwise on special occasions and for special purposes, suggests the question how far there would ultimately be any real distinction of more than a verbal kind between the Bishop's position and a mediating view which should combine the doctrine, upon the one hand, of a miraculous annihilation of our Lord's body in so far forth as it was a body of flesh and blood, with the assertion, upon the other, of such a series of self-manifestations of the risen Lord to the disciples as Canon Streeter and those

in which he asserted it were such as in effect to amount to a denial of it. See his Historic Faith, chap. x. "The flesh," he writes, "of which we speak as destined to a resurrection, is not that material substance which we can see and handle, measured by the properties of sense. It represents, so far as we now see, ourselves in our actual weakness, but essentially ourselves. We in our whole being, this is our belief, shall rise again." The distinction between "resurrection of the body" and "resurrection of the flesh" would in fact appear almost exactly to correspond to the difference between the view of Westcott and the view of mediaeval orthodoxy. 
who think with him affirm. ${ }^{1}$ Such a view would have the advantage of avoiding the crude difficulties which otherwise arise with regard to the Ascension, which it would become possible to interpret as a spiritual vision granted by way of parable to men who had faith to perceive it.

1 A private letter from Bishop Westcott to the Rev. A. G. Robinson, quoted in a discussion on "The Resurrection of Jesus Christ" in the Hibbert Journal for July 1904, is illuminating in this connexion. The Bishop's words are as follows: "Practically I think it is enough for us to say that it was the will of God so to present the phenomena of the Resurrection as to convey the fullest apprehension of the truth. If the body had remained, the idea of continuity would have been lost, and so through the action of God it passed away, or rather was felt to have been taken up. For myself I go further, and venture to apply more general principles. That which we speak of as 'matter' is, so far as I can see, only the manifestation of force, life in the widest sense, under the conditions of space and time. It has in itself no existence. The Lord's life was never interrupted. He lived through death. As long as $\mathrm{He}$ remained under the conditions of earthly life, His body represented the action of His life. When He entered on another form of existence under new conditions His life found a new embodiment." The italics are mine. 
The general outcome of our investigation may perhaps be thus summed up. On the one hand, we do not desire to have the resurrection of our Lord assimilated to a ghost story, and we should be reluctant so to assimilate it. We cannot regard it as probable that the Apostles' despair at the crucifixion of their Lord would have been reversed by anything bearing less concretely the character of actual fact than the crucifixion itself. We do not wish hastily to conclude that the characteristically Christian "sentiment of the body" is wholly sentimental, or necessarily to repudiate the argument that it was unfitting that the sinless One should "see corruption."

But, upon the other hand, it would seem probable that, for some time to come, of those who upon general grounds are believers in the Incarnation-those whose hearts God has touched, and who find in Jesus Christ the Express Image and Revelation of the Father -not a few will be content, while affirming the reality of the resurrection, to leave the 
precise manner of it undefined. And there is surely room for a wise agnosticism.

For the Church can afford to wait. Magna est veritas et praevalet. If it be true that a physical resurrection is alone consonant, in the last resort, with the truth of the Gospel, the fact that it is so will eventually come to be recognized and admitted more universally among Christians than is the case to-day. If, on the other hand, the truth is on the side of the innovators, the legitimacy of their innovation will in time be universally conceded. Those in the meantime are the real sceptics who regard the Christian faith as incapable of maintaining itself without artificial protection. "I cannot praise a fugitive and cloister'd virtue, unexercis'd and unbreath'd, that never sallies out and sees her adversary, but slinks out of the race, where that immortal Garland is to be run for not without dust and heat. . . . And though all the winds of doctrin were let loose to play upon the earth, so Truth be in the field, we do injuriously by licensing and prohibiting to misdoubt her strength." 


\section{IV}

OUR LORD'S VIEW OF THE FUTURE

ORTHODOx theology, as the result of a prolonged process of discussion and reflexion with regard to the significance of the Person of Jesus Christ, eventually arrived at the formulation of the doctrine that in Him were united, in virtue of the Incarnation, two distinct natures, a Divine nature and a human nature, conjoined indissolubly, without either confusion or intermixture, in one Person. ${ }^{1}$ This was an attempt both to assert the obvious and primary fact that He was man, and also to justify the affirmation of Christian faith and experience that $\mathrm{He}$ was and is Divine. The formula of Chalcedon, which

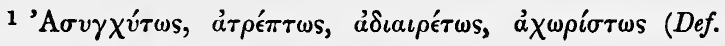
Chalc., A.D. 451). 


\section{OUR LORD \& THE FUTURE 113}

finally crystallized this doctrine, was not so much a solution of the Christological problem as a statement of it. No theory was propounded of the relation in the one Christ of the Divine to the human. It was merely affirmed, in a series of antithetical statements, that $\mathrm{He}$ was perfect God and perfect Man.

Meanwhile popular religion, and much popular thinking which passed for orthodox, has commonly manifested one or other of two tendencies. On the one hand there has been a tendency to treat the Incarnation as a theophany; to think of the historic Christ, in other words, as simply a manifestation of Godhead in human flesh, and to ignore the completeness and genuineness of His manhood. ${ }^{1}$ Popular orthodoxy, to put it technically, has often been unconsciously monophysite. On the other hand there has been a rival tendency to become quasi-Nestorian: not indeed to assume, with the Nestorians proper, the coexistence in Christ of two distinct and separate

1 This is, of course, to rob the Incarnation of all inner reality, and in effect to reduce our Lord to the level of one of the "avatars" of Vishnu in the Hindu "Bhakti" religion. Cf. J. L. Johnston, Some Alternatives to Jesus Christ, pp. 83-86. 


\section{DOGMA, FACT \& EXPERIENCE}

Persons, a Divine and a human; but to assume the co-existence of two distinct and separate capacities, in which the historic person, Jesus of Nazareth, acted by turns. As man, it was held, He slept, but as God He stilled the tempest. When $\mathrm{He}$ spoke in His human capacity $\mathrm{He}$ knew not the day nor the hour; but when $\mathrm{He}$ spoke-as it was assumed that $\mathrm{He}$ commonly did speak - in His Divine capacity, why then, of course, He knew all things. ${ }^{1}$

It is to-day coming to be recognised that such a view, when thought out, is neither intelligible, nor orthodox, nor real. It is unreal, because it dictates an artificial exegesis of the Gospels. It is unintelligible, because it explains nothing and makes Christ a metaphysical enigma. It is unorthodox, because it fails to conserve the doctrine that our Lord

1 This conception of the two natures as two capacities is found very notably in the Tome of St. Leo. Cf. Leo, Ad Flavian., iv. "Esurire, sitire, lassescere atque dormire evidenter humanum est. Sed quinque panibus millia hominum satiare et largiri Samaritanae aquam vivam, cuius haustus bibenti praestet, ne ultra iam sitiat: supra dorsum maris plantis non desidentibus ambulare, et elationes fluctuum increpata tempestate consternere, sine ambiguitate divinum est." 
was truly man. 'To-day it is widely conceded that, whatever be the ultimate mystery of our Saviour's Person, His life on earth was a genuinely human life, mediated from first to last by genuinely human faculties, and involving a human experience which was real and not fictitious. As Canon Simpson has tersely put it, "our Lord Jesus Christ did not endure temptation in an official capacity"; and extending the phrase we may say that His life on earth is to be understood in general as a human life, and not as an official career.

\section{II}

Our Lord came upon earth as a Jew, and as a Jew of Palestine. His life and character, His work and person, all that $\mathrm{He}$ was and did as man, are indeed, as Christians believe, of universal significance and of universal value. He speaks to men of every time and of every race, and men of all times and races find in Him their Pattern, their Redeemer, and their Lord. But the circumstances of His life were nevertheless individual and particular. $\mathrm{He}$ was a Jew, a peasant, a carpenter. In child- 


\section{DOGMA, FACT \& EXPERIENCE}

hood He learnt, as other children learn, at His Mother's knee. He was influenced, doubtless, by the scenery of Galilee, by the surroundings of Nazareth. He read, and probably learnt by heart, the Jewish Scriptures, and possibly certain of the apocryphal writings as well. $\mathrm{He}$ knew no other literature-we should find it hard, for example, to imagine Him as quoting Plato or Thucydides. The atmosphere of His teaching is in effect the atmosphere of the late Judaism of His day.

Certainly the Gospels breathe that atmosphere, and are to be understood, in their primary historical meaning, from that point of view. $\mathrm{He}$ who would interpret the Gospels historically must first have soaked his mind in the thought and literature of the Old Testament, and in the ideas and beliefs and the world-outlook of first-century Palestine; and for the understanding of those ideas and beliefs and of that world-outlook we are to-day in some respects better equipped than any previous generation of Christian scholars, by reason of that rediscovery and that new scientific study of the apocalyptic literature of late Judaism, which has been 


\section{OUR LORD \& THE FUTURE 117}

the great conspicuous triumph of the Biblical scholarship of our day. Much in the New Testament which had been obscure becomes luminous when read in the light of conceptions with which the study of Jewish Apocalypses has made us familiar. The Gospels presuppose, in a word, a background of apocalyptic thought.

\section{III}

As giving, perhaps, the shortest and clearest account which is available of the general nature of apocalyptic thought, I would proceed to quote at some length from Professor Lake : ${ }^{1}$

One of the most important sides of the story of the Jews is a chapter in the history of nationalism. That is to say, it was a phase of the struggle which has gone on throughout the course of civilisation between the great empires and the small nations. The Jew naturally looked at this struggle from the point of view of a small nation, but we can probably grasp it best if we first consider it from the point of view of the great empires.

If we go back some centuries before Christ,

1 Kirsopp Lake, The Stewardship of Faith, pp. 5-6, 8-10 (Christophers, 1915). 


\section{DOGMA, FACT \& EXPERIENCE}

we find the Babylonian empire as the centre of civilisation. If we could have asked an ancient Babylonian how the empire was progressing (though he would of course have expressed it in quite a different manner from the modern phraseology here attributed to him), he would, I take it, have said something like this: "Yes, the empire is flourishing. We have succeeded in extending our boundaries; we have succeeded in civilising a large number of wild and savage tribes; we have brought them into the empire; we have made them useful members of civilisation."

If we had then gone one step further, and asked him to tell us what was the policy of his empire, he would have said: "Well, whenever we find a small nation which is hindering our progress we transplant it. We break it up and move it, a little here and a little there. We transplant it so that it is able more readily to assimilate itself to our civilisation. The process is not always appreciated by the small nation at the time, but it makes for the good of the world in general. . . ."

Such was the attitude of the great nations which once dominated the world. Now let us turn round, and do a much more difficult thing-consider the facts from the point of view of the small nation of the Jews. Instead of looking at history as the triumphal procession of civilisation, they necessarily regarded it much more as the warding off-and the not always complete warding off - of a series of catastrophes. Everything seemed to be constantly going wrong. Actual disaster might be 
averted, but by no possible meaus could they regard the existing state of things as satisfactory. They had thought they were the chosen people; they had expected that dominion and power should be given to them; and they were, at the best, merely fighting for a precarious existence, constantly threatened with extinction by the struggles of great nations.

Under the pressure of that constant adversity, a very peculiar type of thought was developed, and it is this which is especially important as being the ultimate background of the thought of the first generation of Christians. It was intensely monotheistic; it believed in the existence of the one God of the Jews, and of Him alone. It was intensely moral ; it had a high-an extraordinarily high-code of ethics. And the Jews used their monotheistic creed and their high ethical standards as a fence to protect themselves against the aggression of foreign nations. Finally they developed, within the circle of monotheistic ethics, a special catastrophic view of the universe. That is to say, under the influence of their national disasters, they came to regard the whole course of history as a succession of great dramatic catastrophes, and looked forward with hope to the coming of one great, final cataclysm, after which the tyranny of the great nations would be trodden under foot, and the children of Israel would take their place as the chosen people of God, under His direct governance, with His anointed King as His representative on earth. 


\section{DOGMA, FACT \& EXPERIENCE}

That catastrophic view of the universe (which the theologian has learnt to call eschatological, because it deals with the "̈ $\sigma \chi a \tau a$, or "the last things") was the source of a whole literature, which was produced more or less after the close of the canon of the Old Testament, and before, or at the same time as, the rise of Christianity. . . In this literature there was a constant attempt to explain history by starting from the beginning of creation and stating it, not in the terms of actual events, but in the terms of the successive interventions of various supernatural beings, some of which were derived from Babylonian mythology, so that we can trace under the guise of the narrative of these supernatural interventions a series of allusions to the great events in the history of Israel. At the end, however, there is usually given an imaginative sketch of one more great intervention, this time entirely in favour of Israel, which is to close the history of the world as it is now, and inaugurate a new age and a new society, in which there is to be neither enemy of Israel, nor wicked men, nor sorrow, nor any that oppresses, nor any that suffers wrong. That is the picture of the future which they painted.

It is impossible, I think, for any one who will first make himself familiar with the literature and the type of thought which 


\section{OUR LORD \& THE FUTURE 121}

Professor Lake has described in the passage just quoted, and who will then turn to the New Testament documents, to avoid the conclusion that the New Testament writers as a whole presuppose the Apocalyptic and Eschatological Weltanschauung or world-outlook. ${ }^{1}$ They are dominated by the thought of an approaching End; a World-Judgment; a coming of the Messiah upon the clouds. Nor is it less characteristic of the teaching of our Lord Himself than of the writings of His Apostles. "Now after that John was delivered up, Jesus came into Galilee, preaching the Good News of God, and saying, The time is fulfilled, and the Kingdom of God is at hand: repent ye, and believe the Good News." 2 "These twelve Jesus sent forth,

1 The Fourth Gospel is commonly quoted as an exception. "The return of Christ in S. John," writes Dr. Inge, " means His presence in the Church and in the hearts of believers" (Cambridge Biblical Essays, p. 284). I am not sure that I agree that this "spiritual return" is regarded by the Evangelist as the equivalent of the Messianic "Coming": but the very need for such a "spiritualizing" of the Parousia as Liberalism assumes to have taken place bears eloquent though indirect testimony to the eschatological character of the original Gospel.

2 Mark i. 14-15. 


\section{DOGMA, FACT \& EXPERIENCE}

and charged them, saying, Go not into any way of the Gentiles, and enter not into any city of the Samaritans; but go rather unto the lost sheep of the house of Israel. And as ye go, preach, saying, The Kingdom of Heaven is at hand. . . . Verily I say unto you, Ye shall not have gone through the cities of Israel, till the Son of Man be come." " "But in those days, after that tribulation, the sun shall be darkened, and the moon shall not give her light, and the stars shall be falling from heaven, and the powers that are in the heavens shall be shaken. And then shall they see the Son of Man coming in clouds with great power and glory. And then shall $\mathrm{He}$ send forth the angels, and shall gather together His elect from the four winds, from the uttermost part of the earth to the uttermost part of the heaven. . . Verily I say unto you, This generation shall not pass away, until all these things be accomplished. Heaven and earth shall pass away: but My words shall not pass away." 2 "But of that day or that hour knoweth no one, not even the angels in heaven, neither the Son, but the

1 Matt. x. 5-7, 23.

2 Mark xiii. 24-27, 30-31. 
Father. Take ye heed, watch and pray: for ye know not when the time is." " "When ye pray, say, Father, . . . Thy Kingdom come." ${ }^{2}$

In spite of these and other sayings recorded in the Gospels, it has been disputed whether our Lord taught that the Kingdom was present or future; or if future, whether it was to come about by a process of gradual growth and development, or to be suddenly inaugurated by a catastrophic change. The Parables of the Sower and the Leaven have been held to suggest the idea of a gradual growth, and such sayings as "The Kingdom of God is within you," 3 or "If I by the Spirit of God cast out devils, then has the Kingdom of God come upon you unawares

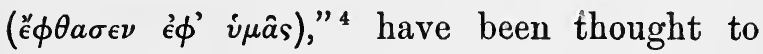
imply a Kingdom already present; and it has been doubted whether the more eschatologicalsounding sayings are genuine. But the Parable of the Sower is simply the reflection of our Lord's experience as a preacher, and describes, not the nature of the Kingdom, but

1 Mark xiii. 32-33.

2 Luke xi. 2 ; cf. Matt. vi. 9-10.

3 Luke xvii. 21.

4 Matt. xii. 28. 


\section{DOGMA, FACT \& EXPERIENCE}

the varying degrees in which differing types of character respond to the proclamation of its approach: and the point of the Parable of the Leaven, like that of the kindred Parable of the Seed growing secretly, is that the process by which the Kingdom comes to pass is wholly the work of God. Like the secret operations of Nature, it will be inscrutable. "The Kingdom of God cometh not with observation." While men are saying "Lo, here! or Lo, there!" suddenly it will be in their midst, ${ }^{1}$ taking them unawares. The casting out of devils is a sign of its near approach.

1 'Evтòs $\dot{v} \mu \hat{\omega} \nu$, no doubt, means "within you": but this interpretation gives rise to very grave difficulties. The saying is not addressed to the disciples, but to the Pharisees ; and the tense in the preceding clause is not present, but future-_ Neither shall they say, Lo, here! or Lo, there!" Moreover, in what sense could the Kingdom be said to be "in" a man? No doubt individuals were, or might be, already "sons of the Kingdom"; but to our Lord's contemporaries the Kingdom itself "was something objective, epoch-making, world-embracing, implying the downfall of the present world-order, and the judgment and rule of God" (Montefiore, The Synoptic Gospels, ii. p. 1013). It seems probable, therefore, that the Greek mistranslates an original Aramaic expression, and that the true meaning is "among you," or "in your midst." 
So, again, the identification of the Kingdom with the Christian Church, which has been based upon such parables as those of the Tares and the Draw Net, is certainly unhistorical. The Draw Net, and the Wheat and the Tares, are parables of the Judgment, which, in the Judaeo-Christian view, is not the climax but the inauguration of the Kingdom. The Church, in the New Testament, is never identified with the Kingdom, but is simply the Messianic Israel, the elect "people of God," continuous with the Israel of old. The fact of a majority of "Israel after the flesh " having "fallen away," and the Gentiles having been "grafted in," so that the Church ceased to be a national affair and became Catholic or universal in its scope, was not held to affect this principle of spiritual continuity with the past. The Church is the spiritual society of those who are destined to inherit the Kingdom when it comes-who are, in short, "heirs of God, and joint-heirs with Christ." 1 The outlook of the first generation of Christians was indisputably eschatological : the evidence of St Paul's two epistles to the

1 Romans viii. 17. 
Thessalonians is in itself decisive upon this point.

Does it follow that what is known as the eschatological interpretation is to be accepted also for the teaching of our Lord? Broadly speaking, I think that it does. No doubt the eschatological idea, taken by itself, does not furnish a complete and all-sufficient clue to everything in the Gospels. Schweitzer's brilliant attempt to force the evidence to fit in with this hypothesis must be pronounced to have failed. No doubt, again, the eschatology of Jesus was "a simpler, wider and greater thing than ordinary Jewish Apocalyptic "; and no doubt also allowance ought to be made for a possible tendency on the part of those who recorded our Lord's words to assimilate His teaching, in so far as it was concerned with the Kingdom, to the details of a stereotyped apocalyptic convention, and to particularize sayings which may originally have been of general application. But that our Lord's own conception of His Messianic vocation and of the nature of the Kingdom of God was in its main emphasis eschato-

1 B. H. Streeter, Foundations, p. 119. 
logical, I for one cannot doubt. He was upon earth for the present as Messias designatus, but His immediate mission was not to be manifested as Messiah; it was to fulfil the rôle of the Lord's Servant, not having where to lay His head, called upon to suffer and to die, and to give His life a ransom for many. ${ }^{1}$ The paradox of Messiahship consisted precisely in the fact that the very same Person who was to do these things was also the claimant of the rôle of Son of Man, the apocalyptic Messiah who was shortly to be revealed in glory as the Judge of quick and dead, and the Lord of the coming Kingdom.

Much of our Lord's language was doubtless consciously symbolical. The narrative of the Temptation, assuming it to be based ultimately upon an acceount given of His experience by the Lord Himself, is an illustration of this; so is His saying on the occasion of the Return of the Seventy-"I beheld Satan fallen as lightning from heaven." ${ }^{2}$ And it is probable enough

1 Luke ix. 58 ; Mark x. 45.

2 Luke x. 18. On the general subject of our Lord's use of symbolism, see Sanday, The Life of Christ in Recent Research, pp. 24 sqq. 
that language which was symbolically meant was sometimes realistically understood. But we cannot fairly explain away, by a theory of radical misunderstanding on the part of the disciples, the generally apocalyptic and eschatological atmosphere of the Gospels. The terms and phrases which our Lord is reported as having used, and the general system of ideas which went along with them, bore a defined and well-understood meaning at the time. It is evident that our Lord's words had the effect of conveying to His disciples' minds the impression that His coming in glory as Messiah upon the clouds of heaven was to be expected in the near future; and indeed it is difficult to see what other impression they could have conveyed. If our Lord's own meaning had been radically other than this, must we not suppose that He would have expressed Himself in terms less inevitably calculated to mislead? It is true that $\mathrm{He}$ is represented as disclaiming exact prediction or detailed foreknowledge of times and seasons. ${ }^{1}$ But $\mathrm{He}$ is also definitely represented as teaching that the fulfilment of all these things was to be anticipated within

1 Mark xiii. 32 ; cf. Acts i. 6-7. 


\section{OUR LORD \& THE FUTURE 129}

the lifetime of the generation then existing. ${ }^{1}$ It was in conformity with this teaching, and in reliance upon it, that the earliest Christians lived in daily and hourly expectation of an approaching cataclysm-a World-Judgmentwhich was to be followed by the bringing in of the Kingdom of God. The fact that they believed themselves to be already in a certain sense inheritors of that Kingdom, and pointed to the new life which they were living, and the Spirit which possessed them, as an evidence that its powers were already at work and in their midst, was itself to them only a pledge of the immediacy of the great event.

And the event in question did not occur. The expectation of the earliest Christians was in a literal sense mistaken. Are we obliged to go further, and to say that their Lord was in a literal sense mistaken also? It is here, surely, that the storm-centre of theological speculation resides at the present moment. It is probable enough that this, and not the controversy about miracle, will be for the next generation the great intellectual difficulty of the Christian religion. It is a difficulty which

1 Mark xiii. 30 ; Luke ix. 27. 
130 DOGMA, FACT \& EXPERIENCE

cannot with honesty be evaded. It can only be met by being resolutely faced.

\section{$\mathrm{V}$}

It is true that the difficulty in question is not, strictly speaking, a new one, though it is felt to-day with a new urgency and emphasis. It has been dealt with in the past by various expedients, none of which are, however, very satisfactory. Many Liberal Protestant scholars have sought to evade the issue by denying either that our Lord taught the eschatological hope at all, or that it was central in His teaching. The discourse in St. Mark xiii. and much of the parallel matter in St. Matthew and St. Luke can be got rid of, it is suggested, by the theory that a short Jewish or JewishChristian apocalypse of the conventional type has been incorporated in the Gospels by mistake. The eschatological significance of other sayings of our Lord is then minimised. The Jewish presuppositions of the disciples and of the earliest Church account, we are told, for the impression made by the Gospels as they stand. Things have been ascribed to Jesus 


\section{OUR LORD \& THE FUTURE 131}

which $\mathrm{He}$ did not really say, and things which He did say have been wrongly coloured. The true kernel of the Gospel is to be sought elsewhere than in the eschatology. It resides especially in the doctrines of Divine Fatherhood and human brotherhood.

I cannot think that this is to interpret the Gospels historically. We only know the teaching of our Lord at all through the reports of His disciples, and if, upon purely subjective grounds of our own, we assume that they so radically and fundamentally misconceived its import, it is difficult to see what grounds we have left for thinking that we have any assured knowledge of what He taught at all. At best, we are involved in an arbitrary and unscientific eclecticism; and certainly it is a difficulty from the point of view of orthodoxy that this Liberal Protestant view involves the elimination from the Creed of the clause, " $\mathrm{He}$ shall come again with glory to judge both the quick and the dead," as being simply the perpetuation of a misconception.

A second familiar line of apologetic is to say that our Lord did preach an immediate Coming, but that we are to find the fulfilment 


\section{DOGMA, FACT \& EXPERIENCE}

of His words either in the illapse of the Spirit at Pentecost or in the downfall of Jerusalem, and with it the overthrow of the established order of Judaism, in A.D. 70. ${ }^{1}$ No doubt it is true that the events in question may not unfairly be said to have signalized the "winding up" of an "age" or epoch in the religious history of the world. They were a $\sigma v \nu \tau \epsilon \lambda \epsilon i a$ $\tau o \hat{v}$ aî̄os. So likewise there is a sense in which each of the great upheavals of history may be regarded as the passing away of a "world." The present World War, for example, is the "end" of the European "world" as it existed prior to the summer of 1914; and any civilization which may eventually be re-established upon its ruins will constitute the beginning of a new and

1 Mark xiii. $14 s q q$, and parallels in Matt. xxiv. $15 s q q$., Luke xxi. 20 sqq. St. Luke evidently regarded "Jerusalem compassed with armies" as an adequate paraphrase for "the abomination of desolation"; nor is this necessarily an interpretatio post eventum. The point which it is of immediate importance, however, to grasp, is that the "abomination" is not the coming of the Kingdom, but a premonitory sign thereof. The more definitely the "abomination of desolation" is identified with the fall of Jerusalem, the more acute becomes the difficulty that the Kingdom did not immediately supervene. 
OUR LORD \& THE FUTURE 133

different "world." Since, moreover, as Christians, "we understand by faith that the

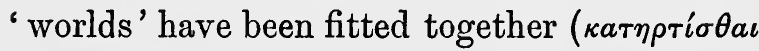

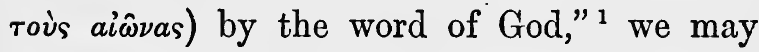
in a certain sense rightly discern in each of the great events of history a "coming of the Son of Man." No other view, indeed, is in the full sense Christian; for upon no other hypothesis can the course of history be interpreted or expressed in terms of a Divine purpose working itself out amid all the immediate chaos and welter of events in accordance with a coherent scheme or plan; and to abandon the conception of a purpose and meaning in history as a whole is a fortiori to abandon it as regards the life-story of individuals, and to destroy at a blow the possibility of faith either in the existence of God or in the value and dignity of man. ${ }^{2}$ "Progress, continuity, and consequence," it has been recently remarked, "are not the only elements in life. There are also present

I Heb. xi. 3.

2 For a suggestive study of Apocalyptic from this point of view, see a paper by the Rev. H. H. Kelly on "Eschatological Interpretations and the War," in the Church Quarterly Review, January 1915. 


\section{DOGMA, FACT \& EXPERIENCE}

catastrophic factors. . . The catastrophic Weltanschauung . . . expresses admirably the catastrophic element in history," though "at the expense of other sides." 1 All this, however, true as it is, does not really meet the difficulty that the earliest Christians were looking for much more than a turningpoint in history, an end of an age. They were looking for the "end of the Age," which was finally to inaugurate the Messianic Kingdom in its fulness; and to resolve the New Testament eschatology into the doctrine of an eternal Presence or a perpetual coming of the Christ is frankly to discard the original meaning of the conception. Certainly to adopt the view which identifies the Parousia of the Son of Man either with the fall of Jerusalem or with the events of Pentecost is to depart widely from traditional orthodoxy. Logically considered, it is as much as to say that the Parousia is past already; and it would follow that the wording of the Creed should be altered, and made to run, "He came again in glory on the day of Pentecost and in A.D. 70, and His Kingdom then began."

1 Lake, The Earliest Epistles of St. Paul, pp. 440, 441. 
But, thirdly, can it honestly be said that traditional orthodoxy itself has faced the issue fairly, in combining a more or less realistic expectation of the Lord's return with the view that a "delay" of many centuries creates no difficulty? The author of the second epistle ascribed to St. Peter, writing presumably some time in the course of the second century, already finds it necessary to discuss and meet objections. "But forget not this one thing, beloved, that one day is with the Lord as a thousand years, and a thousand years as one day. The Lord is not slack concerning His promise, as some count slackness ; but is longsuffering to you-ward, not wishing that any should perish, but that all should come to repentance. But the day of the Lord will come as a thief; in the which the heavens shall pass away with a great noise, and the elements shall be dissolved with fervent heat, and the earth and the works that are therein shall be burned up. ... But, according to His promise, we look for new heavens and a new earth, wherein dwelleth righteous-

1 'The theory of St. Peter's authorship of this epistle is now almost universally abandoned. 
136 DOGMA, FACT \& EXPERIENCE

ness." ${ }^{1}$ Thus was the difficulty tided over but not really met. The realistic expectation of the Lord's return, which held so central a place in the hopes and beliefs of the earliest Christians, fell partially into discredit as the result of the extravagances of the Montanist movement, and in some of its forms came to be condemned as a heresy-Millenarianism. Eschatology continued to form part of the Church's Creed, but it ceased in the old sense to dominate the Church's outlook. That Christ would one day visibly return, that the present order of the world was destined to a sudden and catastrophic ending, that there should be a more or less literal Day of Judgment-so much indeed it was considered essential to orthodoxy to affirm. But the Church came to acquiesce more and more willingly in the indefinite postponement of a crisis which to the first generation of Christians had been the object of eager desire, but to which their successors came to look forward rather with apprehension and dread. The Revelation of St. John ends with the words, "Surely I come quickly. Amen. Even so, come, Lord Jesus." By the

12 Peter iii. 8-10, 13. 
time of Tertullian Christian prayers were already being offered pro mora finis - "for the delay of the End." ${ }^{1}$ The contrast is the measure of a transformation of spiritual attitude which was surely due not so much to a deeper understanding of the Gospel as to the fact that men were beginning to lose their first love. It is the more surprising to find an orthodox writer like Professor H. M. Gwatkin speaking of "the unsettling expectation of Christ's immediate return" as springing merely from "crude literalism and spiritual impatience" : ${ }^{2}$ in effect, those who maintained it were in this respect clinging to the original Gospel.

The difficulty remains, none the less, that the course of history has not conformed to the expectation in question; and there is that in most of us to-day which is more than half disposed to sympathize with Professor Gwatkin's epithets. The question obtrudes itself whether the difficulty does not really go deeper: whether we are really looking for a catastrophic "end of the world," and a visible coming of Christ to judgment, at all :

1 Tert. Apol. xxxix.

2 Gwatkin, Early Church History, ii. pp. 91-92. 
and if so, in what sense are we looking for them?

"Hora novissima, tempora pessima sunt, vigilemus. From such a conception," it has been said, "modern thought has swerved away. For the final coming of Christ in judgment we are given a progressive coming of Christ in history, a series of Divine acts of judgment, in the fall of Jerusalem, the fall of the Roman Empire, the French Revolution, and so on. The Kingdom of God is now a spiritual and moral condition of mankind to be gradually brought about by human effort. It is common to hear missions spoken of as 'spreading God's Kingdom,' or the establishment of the kingdom upon earth spoken of as the consummation to which the work of the Church, social and religious, is destined to lead. . . . How often, again, we hear that verse of Blake's quoted in support of the visions of Christian socialism!

I will not cease from mental strife,

Nor shall my sword sleep in my hand, Till I have built Jerusalem

In England's green and pleasant land.

"In the primitive Christian conception, Jerusalem was not built by any man upon the 


\section{OUR LORD \& THE FUTURE 139}

earth. It descended, adorned already as a bride, out of heaven." ${ }^{1}$

VI

The questions raised by our discussion are certainly sufficiently grave. Was our Lord a true prophet? Did He mislead His Church? Or was He even Himself so far misled as to entertain an expectation about the future which was not to be literally fulfilled? And if so, what becomes of the Christian view of His Person? Or again, are we ourselves still to expect a literal fulfilment? And if not, what meaning or value can the eschatological language and teaching of the Gospel have for us? These are questions which are not easily susceptible of any conclusive or immediate answer of a wholly satisfactory kind. What follows is to be regarded rather as an attempt to think out the lines of a possible answer than as a complete and rounded theory. It claims no kind of finality, but is submitted in a tentative fashion to the judgment of the Christian mind.

1 Edwyn Bevan, The Problem of Eschatology (Liddon House Occasional Paper, No. xii.). 


\section{VII}

It has to be admitted, I think, that the eschatological outlook is no longer ours. The apocalyptic picture of the End has lost for us its literalness, and it is only by a liberal use of the principle of mental reserve that we can bring ourselves to sing such hymns as "Lo, He comes with clouds descending," or "Great God, what do I see and hear?" We are conscious that we do not regard these things precisely as our fathers regarded them. We feel that we are in the region of symbolism, and we are chary of mistaking symbol for reality.

Yet if we ask ourselves, "What, then, is the thing symbolized?" we are hard put to it to find an answer. It may be that we must begin by recognizing that the end of the time-process, the dénouement of that secular process of history in which we are immersed, is strictly unimaginable. We look before and after, but our understanding is baffled as often as it essays to grasp either the Beginning or the End. We have a Creation-myth for the one: must we not have an Eschatological- 
OUR LORD \& THE FUTURE 141

myth for the other? The function of Myth, it has been held, is precisely to evoke in us "Transcendental Feeling"-a solemn sense of ultimate mystery - in relation to realities not directly cognoscible by the understanding. The presentation of truth in such cases under mythological forms is analogous to " some great Ritual at which thinkers may assist, and feel that there are mysteries which the scientific understanding cannot fathom." "He shall come again with glory to judge both the quick and the dead, whose Kingdom shall have no end "- what does it mean to us? Certainly not nothing. The language is that of imagery and symbol ; but a part, at least, of what is implied by the symbolism we may venture to put into words.

That this world's story is not a meaningless progressus ad infinitum; that it is destined to have its culmination in some great justifying Divine Event, which will involve the final triumph of the Christ: that the clue to its mystery is not to be discovered in any merely immanent process of natural evolution, but in a salvation coming down out of heaven from

1 Stewart, The Myths of Plato, Introd. p. 57. 


\section{DOGMA, FACT \& EXPERIENCE}

God: that God is in truth the supreme Actor in history, and that the deepest truth of religion is to be found in the conception of an Advent wherein $\mathrm{He}$ comes to man: that $\mathrm{He}$ is the Eternal Judge of man and of his doings, before whose dread Tribunal all things lie naked and open without possibility of evasion or concealment-" "for there is nothing hid, which shall not be manifested; neither was anything kept secret, but that it should come abroad "; - these at least are among the values which the language of apocalypse enshrines.

And there is another lesson also which such language is meant to enforce-that of the transitoriness of the existing order of things and the illusory character of that presumption of security and permanence which the stability of "a calm world and a long peace" is wont to beget in us. For our own generation, at least, this particular dream has been in dramatic and terrible fashion dispelled. We have witnessed as it were the opening of an apocalyptic seal and the letting loose of War, Famine, and Pestilence upon the world. We have been confronted by the spectacle of "dying men, flowing blood and burning cities." 
We have seen God's judgments in the earth, and we have learnt to realize what is meant by "standing in jeopardy every hour." The lesson has been written in blood across the battlefields of Europe. "Here have we no continuing city, but we seek after that which is to come."

The cloud-capped towers, the gorgeous palaces,

The solemn temples, the great globe itself,

Yea, all which it inherit, shall dissolve,

And, like this insubstantial pageant faded,

Leave not a rack behind.

Eschatology stands, in other words, for the element of "other-worldliness" and detachment in Christianity - the very salt and vital principle of whatever is spiritually sound and true in religion-over against the this-worldly, immanental element, which if left to itself would be in danger of evaporating in bathos and futility. For religion is essentially eternal life: and "neither an Eternal Life that is already fully achieved here below, nor an Eternal Life to be begun and known solely in the Beyond . . . but only an Eternal Life already begun and truly known in part here, though fully to be achieved and completely to be understood hereafter, corresponds to the 


\section{DOGMA, FACT \& EXPERIENCE}

deepest longings of man's spirit as touched by the prevenient Spirit, God." ${ }^{1}$ We in this life have the "earnest" of the Spirit: but if the earnest is mistaken for the capital sum, the Spirit's earthly temples quickly become mere empty and deserted shrines.

\section{VIII}

Along such lines of thought as these we can still find a value for ourselves in the Apocalyptic idea; but it is not here that the real crux resides. The difficulty lies not so much in allowing a symbolical rather than a realistic interpretation of our Lord's language about the Kingdom, as in explaining away the apparent anticipation that the Kingdom of God should immediately appear. That the disciples looked for an immediate coming of the Kingdom we have seen not to admit of doubt. The Lord Himself is represented in the Gospels as teaching that the Kingdom should come with power in the lifetime of some of those who stood by. ${ }^{2}$ Partial fulfil-

1 Baron F. von Hügel, Eternal Life, p. 396.

2 Mark ix. 1, xiii. 30, and parallels in Matt. and Luke ; Matt. x. 23. 
OUR LORD \& THE FUTURE 145

ments of the words of Christ we may trace, if we will, in the course of history both then and since; but when all is said, who, looking upon the world as it is to-day after nineteen centuries of Christendom, will venture to assert that the Kingdom of God has come?

To these difficulties what is in some ways a suggestive answer has been propounded by Professor A. G. Hogg in a little book which has been widely read in recent years. ${ }^{1}$ "Christ," he writes, "dared to entertain the magnificent hope that, in spite of all appearances to the contrary, the consummation of the Kingdom might really be brought to pass in His own lifetime," and $\mathrm{He}$ hoped this in virtue of His " unexampled faith in the limitless power of God." That hope, in the sequel, was unrealized. But it need not have been so. God willed then, and God wills still, to bring in the Kingdom; but the realization of His purpose is made to depend upon the attitude of man, whose co-operation he seeks. Had men had faith as a grain of mustard seed, then truly mountains should have removed,

1 Christ's Message of the Kingdom, by A. G. Hogg (T. \& T. Clark, 1911). 


\section{DOGMA, FACT \& EXPERIENCE}

and the Kingdom would even then have come. But just as it is said in the Gospel that our Lord at Nazareth " could do no mighty work" by reason of the "unbelief" of the people there, ${ }^{1}$ so, it is suggested, the Kingdom of God waits for its consummation upon the faith of men, and is delayed by man's faithlessness even until now.

Doubtless this suggestion, so far as it goes, has within it a certain truth. But it does not carry us the whole of the way. As it stands it appears to mean that our Lord was not mistaken in His faith in the power and willingness of God to manifest His Kingdom, but that $\mathrm{He}$ was in some sense over-sanguine as to the willingness of man to respond. The doctrine presents itself as summoning men to a greater and more whole-hearted faith in God than they have ever yet displayed, and proclaims that, given the existence of such faith, the Kingdom need not tarry, but might in very deed immediately appear. But the summons to exhibit a greater faith than we in fact possess may easily prove a message less of hope than of despair. Is the Kingdom

1 Mark vi. 5-6. 
then dependent upon us? And must all men manifest faith, in order that it may appear? What if it should remain true, even to the end, that "there are some of you which believe not" ? Thus to make the Kingdom dependent for its consummation upon the attitude of man is in effect to put God at man's mercy; and to demand that men should have faith to believe that the Kingdom, even so, will one day come, is in the last resort to ask them to put their trust, not in God, but in their fellows and in themselves. That, surely, is to rob Christianity of its essential character as a faith, not in man, or in the faith of man, but in God. "When the Son of Man cometh, shall He find faith on the earth ?"- -the words suggest that the answer to the question is doubtful; but they suggest equally that the coming of the Son of Man is not in doubt; that $\mathrm{He}$ will surely come, even though iniquity should abound and the love of many wax cold. "In such an hour as ye think not the Son of man cometh." To make His coming depend, as a condition, upon the finding of faith on the earth, is to destroy the certainty of the assurance that $\mathrm{He}$ comes at all. 
The question arises, therefore, whether a method of dealing with the problem which is in some ways more radical may not in the end prove to be more constructive and more satisfying. At an earlier stage in this essay it was pointed out that any coherently-thought-out doctrine of the Incarnation involved the ascription to our Lord of a genuinely human mind and consciousness, and a human experience which was not fictitious but real. It does not indeed follow that we can penetrate the secret of that perfect and sinless human mind and consciousness. There is a pert irreverence which canvasses our Lord's mind and motives " as though He were a living statesman, or one's neighbour in the next house." 1 Quite apart from the instinctive shrinking which we experience from such attempts at psychological analysis, the materials for the gratification of so intrusive a curiosity are wholly lacking. " Our Gospels," writes Dr. Burkitt, " are very far from being a sort of psychological novel

1 Sanday, The Life of Christ in Recent Research, p. 95. 
with Jesus Christ for Hero." ${ }^{1}$ Nevertheless, even while reminding ourselves that in doing so we are entering upon holy ground, we cannot wholly refrain from speculating upon this subject. We are impelled at least to ask ourselves what type of human mind and outlook affords the nearest analogy to that which we may suppose to have characterized the earthly existence of the Son of Man. Legislator, philosopher, statesman or social reformer, for example, we feel instinctively to be inappropriate terms to apply in such a connexion, theologian or moralist to be hardly less so. A rabbi or a teacher come from God His contemporaries sometimes called Him, but His mind was clearly the reverse of that which we commonly know as rabbinic. "Jesus the Prophet of Nazareth in Galilee" 2 has about it a more promising sound, and our suggestion is in fact precisely this, that it is the prophetic type of mind which affords the least inadequate analogy to the human mind of Christ, and that in the study of the psychology of the prophets, and of the kind of outlook upon the

1 Burkitt, The Gospel History and its Transmission, p. 77.

2 Matt. xxi. 11. 


\section{DOGMA, FACT \& EXPERIENCE}

future which is in general characteristic of the prophetic mind, we may hope to find light thrown upon our problem.

\section{$\mathrm{X}$}

The function of the Hebrew prophets was not primarily to forecast future events but to interpret the ways of God to man. Their claim was not in its essence that of the soothsayer or the clairvoyant. ${ }^{1}$ They were, first

1 Powers akin to what we should now call "second sight" appear to have been claimed in early times by those who were known as "seers" (1 Sanı. ix. 6-9; cf. Num. xxiii.-xxiv.), and are ascribed in Hebrew story to such personages as Elijah and Elisha (cf. especially 2 Kings vi. 8-10, viii. 7-13): probably the capacity to "foretell the future" always formed part of the popular conception of a prophet, and there are instances of prophets hazarding predictions about matters of detail in the immediate future: thus Isaiah offers a "sign" to Ahaz (IB. vii. 11), and Jeremial announces the doom of death upon Hananiah (Jer. xxviii. 16-17). When prophecies came to be written down and treasured as sacred oracles they were frequently interpreted as predictive soothsaying by later generations: the prophet to whom we owe Is. xl.-lv. claims the fulfilment of Jehovah's predictions as a proof of His Godhead (Is. xliv. 6-8), and alleges their impotence in this regard as an evidence of the futility of the gods of Babylon (Is. xli. 21-24). Nevertheless the statements in the text are broadly true as regards the main burden of the message of those prophets whose 
and foremost, men uniquely sensitive to spiritual issues, who saw God at work in the world, but who saw also His purposes thwarted and defeated for the time being by the sin and waywardness of man; and their mission was to declare to their contemporaries Jehovah's mind and will, to utter a message from on high. In speaking of the present they spoke also of the future; but their anticipations in this regard were not, as a rule, of the nature of exact predictions, nor was their fulfilment in detail of moment to their essential truth. The Book of Jeremiah, for example, still includes among the prophet's utterances an early foreboding of the coming of judgment against Jerusalem out of the North, ${ }^{1}$ in spite of the fact that the invading Scythians, to whose coming in the year 626 B.c. the passage

writings have become canonical. The later apocalyptic movement was concerned in part with the problem of explaining the non-fulfilment of earlier prophetic forecasts : and those who took part in it shared the more mechanical view of prophecy which was current in post-exilic times. Yet nothing is more remarkable than the manner in which their faith survived the shock of repeated disappointments. "The Kingdom is at hand" is still the burden of their message.

1 Jer. i. 13-15 ; cf. iv. 6, vi. 1, 22. 


\section{DOGMA, FACT \& EXPERIENCE}

probably refers, did not actually reach Judaea, but advanced upon Egypt by the coast road through Philistia, and were eventually bought off by the Egyptians. ${ }^{1}$ It is likely enough that the prophet's failure on this occasion to forecast accurately the course of events went far to discredit his message in the eyes of his countrymen at the time, and may partly explain why his subsequent preaching fell so largely upon deaf ears. But the fact of the oracle in question having been literally unfulfilled did not lead the prophet, or those who collected and edited his writings, to suppress it. Judgment did fall upon Jerusalem, though the agents of her destruction were not Scythians from the North but Babylonians from the East; and the vision of the seething caldron, whose face was from the North, is retained in the sacred text as a true word of the Lord, justified not in the letter, but in the spirit. So also in like manner Ezekiel, in a group of prophecies referring to Tyre, announces the immediate downfall and annihilation of the city, utters a dirge over its former splendour, and proclaims the dire punishment of its king

1 Herod. i. 105. 
for his arrogance ${ }^{1}$ though as a matter of fact Nebuchadnezzar, after besieging Tyre for thirteen years ( $585-573$ B.c.), failed to take it, and was obliged to raise the siege without any decisive result in favour of the Babylonians, as Ezekiel himself later on admitted. ${ }^{2}$

In all true and historical interpretation of the Old Testament it is, in short, essential to draw a clear distinction between prophecy and soothsaying, and rigorously to eliminate from our minds the notion that what the prophets give us is history written beforehand with miraculous prevision. Speaking generally, the message of all the prophets is in substance very much the same. They looked for a judgment of God upon human sin, and for the realization, in and through and beyond the judgment, of God's ideal for Israel and for the world. The difference between the earlier conception of an ideal kingdom to be established by a representative of David's line, and the later apocalyptic vision of a transcendental Divine Kingdom to be manifested from on high, is at bottom a difference in the form rather than in the substance of the message.

1 Ezek, xxvi.-xxviii.

2 Ezek. xxix. 17 sqq. 


\section{DOGMA, FACT \& EXPERIENCE}

However they conceived of the manner of its coming-whether by natural evolution or by catastrophic intervention from on high-the Kingdom for which they looked was a Kingdom of God : its essence was the realized and effective sovereignty of Jehovah in the world which was His ; and there is one characteristic running throughout their writings which is both remarkable in itself and also strikingly significant in connexion with our present problem : it is that they expected the Kingdom of God immediately to appear. Side by side with this characteristic must be considered another remarkable fact, namely, that the repeated failures of their words to find in the immediate future any adequate fulfilment left both them and their successors, so far as regards their essential faith, wholly unperturbed.

Isaiah, for example, if the Messianic passages ascribed to him are really his, appears to have looked for the manifestation in the more or less immediate future of an ideal Prince of David's line, endued with attributes bordering upon the Divine. ${ }^{1}$ No such anticipation was literally fulfilled. So

1 Isaiah vii. 10-16 ; ix. 1-7 ; xi. 1-9 ; xxxii. 1-8. 
also the glorious forecasts of an ideal redeemed community which the victorious career of Cyrus called forth from the so-called "Deutero"Isaiah" found no adequate fulfilment in the "day of small things" 2 which ensued. Zechariah and Haggai regarded the disturbed state of the Persian Empire at the time of the accession of Darius as heralding the advent of the New Age. ${ }^{3}$ The author of the Book of Daniel looked for the inauguration of the Kingdom of the saints of the Most High to take place within "half a week" or "a time, times and an half" (i.e. three and a half years) of the date at which the book was written. ${ }^{4}$ There is reason to think that many of the religious party of the "Hasîlîm" or "pious ones" were disposed to identify Simon Maccabaeus, or a little later-for a time at least-John Hyrcanus, with the long-expected Messiah. ${ }^{5}$ Each successive generation in Israel

1 Isaiah xl.-lv. ; cf. especially xlv. 1.

2 Zech. iv. 10.

3 Haggai ii. 7, 9, 20-23 ; Zech. i. 15,21 ; ii. 9-13 ; vi. 8.

4 Dan. ix. 27 ; xii. 7. The Book of Daniel appears to have been written about 166 B.c., shortly after the outbreak of the Maccabaean War.

5 Psalm cx. is sometimes considered to have been addressed originally to Simon Maccabaeus, who virtually combined 


\section{DOGMA, FACT \& EXPERIENCE}

appears, in short, to have held that the era of fulfilment was at hand $;^{1}$ and it is probable that in each succeeding generation the prophetically-minded would have echoed the words of Ezekiel, who declared, in opposition to those who asserted that "The vision that he seeth is for many days to come, and he prophesieth of times that are far off," "Thus saith the Lord God... The days are at hand, and the effect of every vision." ${ }^{2}$

It is a constant characteristic, which may not be either ignored or explained away. It is of capital importance for the understanding of the prophetic mind. Only a shallow criti-

regal with priestly functions. Dr. Charles thinks that the Messiah is identified with John Hyrcanus by the writer of the Testaments of the XII. Patriarchs.

1 For a remarkable example of the manner in which ancient prophetic anticipations were repeatedly reinterpreted and applied in successive generations to new historical conditions, compare the history of the oracle of the "seventy years" (Jer. xxv. 11; xxix. 10); the use which is made of it in Zech. i. 12, its reinterpretation in Daniel (Dan. vii. 25,26 ; ix. 2, 25-27 ; xii. 7), and again in Enoch (the vision of the "Seventy Shepherds"-Enoch 1xxxix. 59 sqq.). Dan. vii. is, moreover, in turn reinterpreted in iv. Ezra (=ii. Esdras) xii. 11, 12. See G. A. Cooke in the Expositor for 1909, pp. 205 sqq.

2 Ezek. xii. 27, 23. 
cism will dismiss it as a mere illusion. The prophets of Israel, whatever they may have been, were not simply deluded enthusiasts. The hope of the Kingdom, to which they clung, and the advent of which they proclaimed, was more than an empty dream. Yet it presented itself to their minds as the hope of something which should immediately come to pass; and when, time and again, their anticipations appeared to be refuted by the facts, they were still found to declare with the old undismayed assurance that the Kingdom of God was at hand.

\section{XI}

The truth would appear to be that the prophets expressed in the terms of the proximity of the Kingdom their assurance of its certainty. The prophet is neither clairvoyant nor soothsayer, and prediction is not the essence of his rôle. $\mathrm{He}$ is a man who, on the one hand, is acutely conscious that the world is not what it ought to be-the gap between the ideal and the actual yawns widely in direct proportion to his vision of 
158 DOGMA, FACT \& EXPERIENCE

what the ideal might be; and on the other hand, he is the man who, because of the intensity of his faith in God, is sure that the ideal must be realized. The apparent defeat of God in the world as it is cannot be the last word. The kingdoms of this world must eventually pass away. The Kingdom of God must come.

God must and will bring in the Kingdom. The prophet's faith projects it upon the canvas of his vision. It dominates his outlook. That the Kingdom must come is the one thing about the future of which he feels sure. $\mathrm{He}$ sees it hovering upon the immediate verge of expectation. Like a man beholding a distant city in clear air acrosss a level plain, he sees it so sharply defined that it seems close at hand. His certainty assumes the form of immediacy, and it is psychologically inevitable that he should see the Kingdom as a thing that is near. It is within his horizon, and a man's horizon is short. Threescore years and ten is its utmost limit. And to the prophet the Kingdom is in sight.

A modern example may help to make the point clear. Probably what is in some ways 
the most powerful religious influence in recent years upon the younger generation of the educated classes of both sexes has been that of the World's Student Christian Federation, an organization which originally came into existence in connexion with a recruiting campaign on behalf of Christian Missions. The movement adopted as a kind of watchword the phrase, "The Evangelization of the World in this Generation." That mankind as a whole will actually be evangelized within a generation is extremely improbable. Regarded as a prediction the words would be calculated to mislead. Regarded, however, as a prophetic or apocalyptic vision, they embody a deeper truth than the most accurate of forecasts could have conveyed; for they bring the goal within the horizon. They exhibit the ideal, not as something dim and remote and shadowy, but as something vivid and close at hand, full of present inspiration and power.

\section{XII}

It is along some such lines as these that I would venture to suggest that we ought to 


\section{DOGMA, FACT \& EXPERIENCE}

look for the clue to the interpretation of the apocalyptic outlook. There is set before us alike in the prophets, in the Christian Creeds, and in the words of our Lord Himself the vision of the coming of God's Kingdom; and the certainty of its arrival is expressed in the terms of an assertion of its proximity. Times and seasons the Father hath set in His own power. But the Kingdom, whensoever and in whatever form it comes, is in any case the gift of God and no achievement on the part of man. No process of merely secular evolution can avail to bring it about: no human striving can produce it. There is that in man which transcends the limitations of the natural order and demands a satisfaction which no merely earthly Paradise could ever afford. The true Jerusalem is the new Jerusalem that cometh down out of heaven from God. And because God is God, there must ultimately be a satisfaction for the cravings of the heart of man.

For thee, $\mathrm{O}$ dear, dear country,

Mine eyes their vigils keep-

it is the other-worldliness of the Christian ideal which alone gives meaning and signifi- 
cance, in the last resort, to the life here and now upon this earth. Only when life is seen to be pregnant with eternal issues does it begin to be important. If Christ asks of men detachment from the things of earth, it is in order that He may give them back again transfigured by the radiance of the things in heaven. He leads them back into their own country by another way. "You never enjoy the world aright," writes Traherne, "till you see how a sand exhibiteth the wisdom and power of God: And prize in everything the service which they do you by manifesting His glory and goodness to your Soul, far more than the visible beauty on their surface, or the material services they can do your body." 1 So far from preoccupation with the life to come rendering this life ineffective, it is in mere historical fact the practical mystic who alone has moved the world. The merely practical person who is not a mystic has never permanently moved the world. Of all worthy and lasting monuments of human genius, of all good work done and all effective striving for the glory of God and the good

1 Thomas Traherne, Centuries of Meditations, i. 27. 


\section{DOGMA, FACT \& EXPERIENCE}

of man, the lines are true which were written of King's College Chapel-

They dreamed not of a perishable home Who thus could build.

The forms in which faith finds expression are necessarily symbolic. The vision of the coming of the Son of Man in glory upon the clouds of heaven is doubtless as symbolical in form as the descent of Christ into hell. Our Lord used this language as the only language which was available for Him to use, clothing His thought in the only forms under which it was possible for Him to think, in order to express truths transcending symbolism: the truth of Divine judgment as an eternal fact, the truth of the Divine Kingdom as a sure and certain hope and of His own relation to that Kingdom, the truth of the transcendent character of the only salvation which could ever satisfy the mystical needs of man.

To declare our Lord's vision mistaken is to impugn the truth not of His words alone but of those of all the prophets of our race. It is to prefer the rationalism of the superficial cynic to the insight of the man of God. It is to treat prophecy as prediction and to reduce 
OUR LORD \& THE FUTURE 163

poetry to prose : to try the vivid intuitions of Oriental genius by the unimaginative standards of the West.

"Where there is no vision the people perish." The matter-of-fact Western still finds difficulties because the vision is unfulfilled. I believe that if our Lord stood again visibly amongst us, as once $\mathrm{He}$ did in Galilee and Jerusalem, and if $\mathrm{He}$ were to be asked whether in what He said He had been wrong, He would answer "No." "My picture of the future," He would say, "as it then was present to My mind has not been literally fulfilled. The generation to whom I spoke did not witness the full coming of the Kingdom, though they did see it come, in a certain sense, with power. That which has happened, that which is happening and will happen is the accomplishment, not of the letter, but of the spirit of My words. Heaven and earth shall pass away, but My words shall not pass away." 


\section{V \\ CLERICAL VERACITY}

I

IN the course of the month of October 1913, the Bishop of Zanzibar addressed to the Bishop of St. Albans an "Open Letter," in which he spoke of the Church of England as having an " exceedingly chaotic system of Truth," and declared that "the Ecclesia Anglicana needs at once to choose between the liberty of heresy and the duty of handing on the Faith as she received it." Easter 1914 saw the publication by the Bishop of Oxford of The Basis of Anglican Fellowship, a pamphlet written with specific reference to the Bishop of Zanzibar's complaint, and addressed in the form of an open letter to the clergy of the diocese of Oxford. The Bishop of Oxford's pamphlet dealt, like that of the Bishop of Zanzibar, with 
other issues besides that of theological Liberalism, but it is with his treatment of the latter subject that this essay is concerned. Pointing out that an "advanced" school of biblical criticism had arrived at certain conclusions of a kind which would be generally regarded as unorthodox, the Bishop proceeded to discuss at some length the claim which " a considerable number of clergymen" were putting forward that the maintenance of the conclusions in question was not incompatible with the continued exercise of their ministry in the Church, and to express his judgment that "if this claim be allowed, so far from 'commending itself to every man's conscience in the sight of God,' the Church which tolerates this claim will be publicly convicted of insincerity, and will lose all moral weight with the mass of Englishmen. ..." "We shall more and more lose both the reputation and the reality. of sincerity," added the Bishop, "unless we repudiate, solemnly and directly, the claim which, as I think, is inconsistent with the veracity required in all public professions." ${ }_{1}$

In consequence of the challenge thus pre-

1 The Basis of Anglican Fellowship, p. 15. 
166 DOGMA, FACT \& EXPERIENCE

sented to the Church, the Archbishop and Bishops of the Province of Canterbury, assembled in Convocation, proceeded to pass the following Resolutions:

Inasmuch as there is reason to believe that the minds of many Members of the Church of England are perplexed and disquieted at the present time in regard to certain questions of Faith and of Church Order, the Bishops of the Upper House of the Province of Canterbury feel it to be their duty to put forth the following Resolutions:

1. We call attention to the Resolution which was passed in this House on May 10, 1905, as follows :

"That this House is resolved to maintain unimpaired the Catholic Faith in the Holy Trinity and the Incarnation as contained in the Apostles' and Nicene Creeds, and in the Quicunque $V u l t$, and regards the Faith there presented, both in statements of doctrine and in statements of fact, as the necessary basis on which the teaching of the Church reposes."

We further desire to direct attention afresh to the following Resolution, which was unanimously agreed to by the Bishops of the Anglican Communion attending the Lambeth Conference of 1908 :

"This Conference, in view of tendencies widely shown in the writings of the present day, hereby places on record its conviction that the historical facts stated in the Creeds are an essential part of the Faith of the Church." 
2. These Resolutions we desire solemnly to reaffirm, and in accordance therewith to express our deliberate judgment that the denial of any of the historical facts stated in the Creeds goes beyond the limits of legitimate interpretation, and gravely imperils that sincerity of profession which is plainly incumbent on the ministers of the Word and Sacraments. At the same time, recognizing that our generation is called to face new problems raised by historical criticism, we are anxious not to lay unnecessary burdens upon consciences, nor unduly to limit freedom of thought and enquiry, whether among clergy or among laity. We desire, therefore, to lay stress on the need of considerateness in dealing with that which is tentative and provisional in the thought and work of earnest and reverent students. ${ }^{1}$

It is evident that in the Resolutions just quoted and in the discussions which led up to them, three several and distinct issues are really in question: there is in the first place the issue of truth, or in other words, the question whether the assertions of orthodoxy as formulated in the Christian Creeds are in fact true; there is in the second place the

1 Chronicle of Convocation for the sessions of April 29 and 30, 1914. 


\section{DOGMA, FACT \& EXPERIENCE}

question of the anomalous position of clergymen whose beliefs are of doubtful orthodoxy, as accredited exponents of the mind of the Christian Society; and there is thirdly the question of the personal sincerity of such clergymen in view of the obligations in the way of belief which are involved in their clerical profession. We may distinguish the three issues as theological, ecclesiastical, and ethical respectively. They constitute a group of closely related problems; but it is very important that they should not be confused, since it is only in abstraction from the sideissues raised by the other two that any one of the three can be fairly considered upon its merits. Our concern in the present essay is primarily with the third, that is to say with the ethical problem; but it appears desirable, in order to clear the ground, to devote a few words, by way of preliminary, to the ecclesiastical and theological issues also, since it is in connexion with the bearing upon ecclesiastical discipline of recent theological tendencies that the subject of clerical veracity, which was discussed some years ago, as the Bishop of Oxford reminds us, by the late Henry 
Sidgwick, ${ }^{1}$ has once again been brought into prominence.

\section{III}

It has been the business of the theologian, all through the Church's history, to study, to investigate, to interpret and to express in new ways the truths which lie at the basis of Christianity; it has been his business, in a word, to translate Christianity, upon its intellectual side, into such terms as shall be intelligible to his contemporaries. Just as students of history know well enough that all periods are transitional and all times are in greater or less degree times of crisis, so students of historical theology know that all periods have been periods of doctrinal restatement and reinterpretation. Theology, wherever it has been a living discipline and not merely an unthinking tradition, has claimed emancipation

1 "The Ethics of Religious Conformity," by Henry Sidgwick, appeared as an article in the International Journal of Ethics for April 1896. Dr. Rashdall replied in the same journal in January 1897, and Dr. Sidgwick reprinted his original paper, together with an essay on "Clerical Veracity" in answer to Dr. Rashdall, in the volume called Practical Ethics which he published in 1898. 


\section{DOGMA, FACT \& EXPERIENCE}

from the dead hand of the past: theologians have thought things out afresh, and have aimed at expressing in their own terms and in their own way the permanent content of the Christian revelation. Each succeeding generation has consequently its own problem of modernism to face, and in each succeeding generation there is apt to be a certain amount of tension between the rival claims of authority and of intellectual freedom. Properly regarded, each is essential to the other: authority has no value except as the free consensus of independent minds; freedom of thought and enquiry, interpreted as a mere licence of emancipation from the past and pursued without reference to the witness of tradition, is liable to issue in conclusions more negative than true.

In our own time the problem of adjustment has been in some ways especially acute. For one thing, the critical movement has certainly come to stay: and yet even now, after a hundred years of criticism, the mind of the Church as a whole has not completely adjusted itself to the new method, nor have the Church's thinkers as yet fully arrived at a constructive 
synthesis of theological truth, critically based. For another thing, the mind of to-day is unmistakably reluctant to commit itself with any degree of positiveness to belief in the miraculous. It is possible that the cause may lie in a defect in the ruling philosophy, or in a failure adequately to criticize the presuppositions of the historical method; it is possible that the conception of the miraculous itself is in need of some degree of restatement or of reinterpretation. For the present the fact remains that men find miracles a difficulty, where their fathers found them a help; and though this, of course, does not in itself settle the question of miracles either way, it at least constitutes a strong temptation to the theologian to avoid, in so far as he may, the presentation of Christianity as dependent upon the historical truth of miraculous events.

Once more, the minds of men to-day are to a large extent dominated by the conceptions of evolution and of development. There is certainly traceable in the history of Christianity a development of dogma; and there has been a recurrent tendency on the part of theologians to slip into the habit of thinking of a develop- 


\section{DOGMA, FACT \& EXPERIENCE}

ment, not merely of the forms of theological expression, but of the content of Christianity itself. A recent writer practically defines Christianity as movement, ${ }^{1}$ and appears to regard it as the essential characteristic of true religion that it should be always changing into something else. It is obvious that in such a conception there is an enormous exaggeration. However men's interpretations of spiritual values and formulations of spiritual truth may vary from age to age, religious truth itself (towards an apprehension of which men approximate in varying degrees) does not in any essential matter change. The history of the past is not alterable, nor is the fundamental relation of man to his Maker affected by the flight of time. If a certain view of the universe, as Mr. Chesterton has somewhere put it, is true at half-past ten in the morning it is also true at half-past eleven. If it ever was true that our Lord rose from the dead, it is as true to-day as it was in the first century A.D.

1 Kirsopp Lake, The Stewardship of Faith, p. 162 : "Christianity has always been a movement : the stewardship of faith is to carry on the movement." 


\section{CLERICAL VERACITY}

Now, it must be admitted that much current modernism has been disposed to play fast and loose with truth, both historical and dogmatic, and that much critical writing has been rash and ill-considered. The temper of mind which reads the words in the Commination Service- "Cursed is he that removeth his neighbour's landmark" - with a mental reference to Broad Churchmen has not been without a certain show of excuse. When the Bishop of Oxford utters a warning against light-hearted modernisms, or reminds academic theology that the religion of the study may easily get out of touch with life, it may well be that he is performing a needed service. To say that particular scholars and critics are in some danger of letting slip, as unnecessary props or outworn fetters, elements of traditional Christianity which are really vital to practical religion and essential to the completeness of Christian truth, and that a Christianity without miracle means a Christianity evacuated of the secret of its power, may well be to say no more than the truth. It is a tenable view that the Apostles' Creed represents a necessary minimum of dogmatic 


\section{DOGMA, FACT \& EXPERIENCE}

requirement; and it is certainly the case that the Creed was historically intended to involve the assertion of our Lord's Birth of a Virgin, and also (though this is not actually stated in the Creed itself) that His Resurrection was historically understood to have involved the resuscitation in some sense of His physical flesh.

Individuals among those whom the Bishop of Oxford rather vaguely describes as "the critical school" or "the learned clergy" may have been in danger of drifting into positions which, if it would be unfair to describe them as no longer recognizably Christian, at least represent a somewhat serious departure from the common mind of the Church. No duty, indeed, is more rigorously incumbent upon a Christian scholar than that of entire intellectual honesty. God is to be served with a man's whole mind as well as with his whole soul and heart, and there can be no more unchristian temper than that of the intellectual cowardice which refuses to face issues, or tolerates the suspicion that Christianity is unable to endure the test of candid enquiry. Nevertheless the individual Christian, if he 
is wise, will not depart from the common mind and tradition of the Church, in matters hitherto regarded as vital, without grave reluctance and much searching of heart. It is in an especial sense the function of the Bishops, in virtue of their office, to act as the responsible guardians and stewards of the Christian tradition; and a warning such as is contained in the utterance of the Bishop of Oxford-still more the considered and deliberate statement on the part of the Bishops of the Province of Canterbury that certain matters are in their judgment essential to the Christian faith-ought not lightly to be disregarded. The Bishops are not, indeed, infallible; nor are they, except in a few instances, experts in theology; but they are men of sober judgment and wide experience in the pastoral office: they represent the claims of practical religion in the same sense and degree as "the learned clergy" represent the claims of scholarship; and in the determination of these grave matters scholarship and practical piety must both be allowed a voice. Even those, therefore, who do not agree with the substance of the Bishops' state- 
176 DOGMA, FACT \& EXPERIENCE

ment as to what is essential ought to be able to agree that it was right that it should have been made. It does not settle the theological issue, but it is one of the data which ought to be taken into account in the process of arriving at a theological judgment.

The ecclesiastical question, which is the second of the issues involved, is in some respects simpler, or rather, its difficulties are less theoretic than practical. It turns upon the right and duty of the Church, as a spiritual society charged with the proclamation of a specific message, to secure that those who are accredited and authorized to teach in her name adequately express and represent her mind. It is difficult to see how there can really be room for any difference of opinion here in principle. The position of an accredited teacher of Christianity involves obligations and responsibilities which are the concern not merely of the individual in question but of the Church in whose name he speaks. In no society can official authority and status be claimed by 
individuals as a right; and an authority conferred upon an individual subject to the understanding that in his discharge of the duties involved by it his teaching will follow certain lines can neither guarantee the permanence of his convictions nor destroy the inherent right of the society to withdraw its sanction in the event of a disagreement. The Christian minister, as an individual, is intellectually free; but if in the exercise of intellectual freedom he should come to hold and to propagate beliefs or disbeliefs which are repugnant to the Church's mind, he has in fairness and equity no grievance or right of reply, if in the sequel he should be told that he no longer represents the Church in what he teaches, and must forfeit his official authority to be her spokesman.

The point has been forcibly expressed by the Dean of Christ Church in an analogy. "Let us suppose," he writes, "that the Church Association, in order to spread its principles, organises a body of persons who are prepared to go and lecture on the tenets of the society, and especially on the errors of the Church of Rome. Now let us suppose that Mr. A., a 


\section{DOGMA, FACT \& EXPERIENCE}

lecturer for the Association, studies the question of the Infallibility of the Pope, and becomes profoundly convinced that the Papal claims in this respect are justified. $\mathrm{He}$ is so completely sure that his conclusions are right that he feels no hesitation in continuing to lecture for the Association and in receiving his stipend for his work. He is sure that the real interest of the Association is in the propagation of truth, rather than in the maintenance of any particular doctrine, and therefore he does not resign his office. He is aware that he is contradicting one of the central tenets he has agreed to defend, but he consoles himself with the thought that the people who listen to him will be getting fuller truth than if he had maintained the thesis of the Association. There is no doubt what would happen, as soon as the executive officers of the Association found it all out. They would dismiss Mr. A., and tell him to be thankful that they had not prosecuted him: and there is no doubt that all ordinary Englishmen would agree with their action; partly from the facts of the case, partly from their extreme dislike of Romanism. If Mr. A. argued: ' I have a high and austere 


\section{CLERICAL VERACITY}

sincerity which belongs to me as a scholar, and which compels me to set out the highest truth I can find: it is you that are really deceiving the public, by insisting on the propagation of views which I have convinced myself are false': there would be a complete answer. The officers of the Association would reply: 'This has nothing to do with us. You accepted a position in our employ in order to propagate certain opinions which you said you held at the time. You say now that you have changed your mind about them. But the Association has not changed its mind. We quite admit that you have arrived sincerely at your present conclusions. We do not want you to teach opinions in which you no longer believe: but also we do not want you to teach in our name opinions in which we do not believe. So we must part.' I think that any ordinary man would agree that this decision is right and reasonable, and that the matter is one in which the ordinary man is a competent judge." 1

The principle is clear, and ought to be beyond the range of dispute. The Church may

1 T. B. Strong, The Miraculous in Gospels and Creeds, pp. 7-8. 


\section{DOGMA, FACT \& EXPERIENCE}

at any moment say to any of her accredited teachers that his teaching no longer expresses her mind. There is room for divergence of view as to the point at which the line must be drawn; but that a line must be drawn sooner or later between what is and what is not a permissible variety of doctrine there ought to be general agreement. The question of the actual point at which the line should be drawn is in a certain sense a question less of principle than of expediency. ${ }^{1}$ On the side of strictness there is the advantage to the Church which arises from the presentation of a united front and from speaking with a single voice. It is this which has always been one of the great sources of the attractiveness of the Church of Rome. But on the other hand, unanimity may be purchased at too great a cost: it loses its value and impressiveness as soon as it ceases to represent a

1 This is not, of course, to say that the Church and her rulers have no moral obligation in the matter. They are under moral obligations both to the past and also-a fact which is sometimes overlooked - to the future. "Things new and old "- the instructed Scribe will bring both out of his treasure. The conservatism of the ecclesiastical mind, rightly conscious of the duty of safeguarding the heritage of the past, is not uncommonly slow to recognize the parallel duty of welcoming new or unfamiliar truth. 
free consensus of individual minds. The record of past heresy-hunts is not such as to create a praejudicium in favour of heresy-hunting as a method, and the application of ecclesiastical discipline in any given case of heresy can always be plausibly represented as an instance of obscurantism and bigotry. Unquestionably the Church must remain loyal to the Gospel with which she is entrusted, and has the duty of handing down unimpaired the Christian faith in its fulness. But the Church solemnly enjoins upon her ministers the duty of study : it is her honourable and ancient tradition both to encourage learning and to foster the spirit of enquiry and research, in the assured certainty that the Lord is a God of knowledge, and that whatsoever things in the end of the day are true and approved will serve rather to the confirmation than to the overthrow of faith. She has no interest in the maintenance of orthodoxy at the expense of truth, but on the contrary would have truth and orthodoxy coextensive. Her scholars and divines must needs engage in the open arena, and meet all intellectual issues as they arise in a free and candid spirit. 


\section{DOGMA, FACT \& EXPERIENCE}

Rather by force, of circumstances than from any intrinsic necessity, a majority of those who are, in a serious sense, students of theology have always been drawn from the ranks of the clergy ; and it therefore becomes highly expedient to allow in the case of those who are both students and teachers the widest liberty which is compatible with loyalty to the Gospel. If a state of things should arise in which on the one hand particular articles of the faith were gravely questioned, not merely from without but from within the Christian fold, and it was openly doubted whether they were in any real sense essential to the faith; and on the other hand the impression were created that no clergyman could investigate them freely except at his peril; the immediate results could only be of a most disastrous kind. It would be impossible for educated clergy to shut their eyes to the problem. The timid would be tempted to be insincerely orthodox; the hyper-conscientious would be tempted to decide the issue in the negative sense through fear of insincerity ; and such as in all honesty arrived at a positive and orthodox conclusion would be exposed to the taunt of "floundering 
in the muddy ditch of deanery and prebend" and allowing their judgment to be biassed by considerations of worldly prudence.

At the present time the questions of our Lord's Birth and Resurrection are being freely canvassed in the world of scholarship and theological learning, and the last word is very far from having been said upon either of these subjects. Those whose business it is to engage in serious theological study, whether at the universities or elsewhere, are compelled to face these issues, and in many cases for the time being to suspend judgment with regard to them. It is obvious that any one who is led definitely to conclude that the story of the Virgin Birth is untrue, or that our Lord did not rise physically from the dead, cannot possibly claim to be in these particular respects representative of the general mind of the Christian Church as at present advised. It is at least a highly tenable opinion that such denials will never prove representative of the Church's mind. But the challenge has been definitely made, and the question in set terms raised as to whether the assertion of the tenets in question is essential to the Christian faith: 
184 DOGMA, FACT \& EXPERIENCE

and a question and a challenge of this nature can be met only by being faced. Simply to raise the cry of heresy is worse than useless. What is needed is free and candid investigation: and, accordingly, many of those who have the cause of Christianity most earnestly at heart would be disposed to wish that for the present the attempt should not be made to draw too rigorous a line in respect of the matters in question. The toleration, in the case of an individual here and there, of a position admittedly anomalous, might well seem a less grave evil than any action suggestive of a desire to foreclose enquiry by invoking the methods of authority.

The Bishops of the Canterbury Province, in the Resolutions already quoted and referred to, and even more emphatically in the speeches which were made in the Upper House of Convocation on the occasion when the Resolutions were passed, have made it plain that they do not desire unduly to limit freedom of thought and enquiry, and in expressing their judgment that " the denial of any of the historical facts stated in the Creeds goes beyond the limits of legitimate interpretation" they are studious to 
refrain from the condemnation of any state of mind which falls short of actual and overt denial. Nor is it clear that even in regard to individual scholars who might be led, for example, in the case of the Virgin Birth or of the empty tomb, to express definite disbelief, they would necessarily feel bound to undertake disciplinary action. They are content for the time being simply to place it upon record that they cannot recognize such a position as legitimate.

\section{v}

Entirely distinct both from the theological and from the ecclesiastical question is the question of personal honesty. It is the question which is raised by the Bishop of Oxford when he speaks of the claim of the "liberal" clergy to be allowed to continue in the exercise of their ministry as "inconsistent with the veracity required in all public professions," and describes the clergymen in question as a "group of men, no less good and great than the Jesuits, no less zealous in a good cause-but like them led on in a special atmosphere to adopt a position and maintain 


\section{DOGMA, FACT \& EXPERIENCE}

a claim which, looked at in the light of common morality, proves utterly unjustifiable." So also the Bishops in their Resolutions assert in somewhat more guarded language, with regard to the denial of facts stated in the Creeds, that it " gravely imperils that sincerity of profession which is plainly incumbent on the ministers of the Word and Sacraments." ${ }^{2}$

Now it is undeniable that circumstances might arise in which a particular clergyman, quite apart from any overt ecclesiastical censure passed upon him, might come to feel that his position as a Christian minister, in view of the disparity between his personal beliefs and those of the Church in whose name he was set to minister, had become so difficult as to render it impossible for him to continue to exercise ministerial functions without implicit dishonesty; and in such a case an honourable man would have no alternative except to retire into lay communion, even if he did not feel obliged to recede altogether from the fellowship of the Christian Church. To a great extent the

1 The Basis of Anglican Fellowship, pp. 15, 25.

2 Vide supra. 
individual must judge for himself in such matters-" to his own Master he standeth or falleth"-guided by his own personal conscience and by his estimate of what is reasonable and honest. Certainly it would seem that if he has taken due occasion to make his precise attitude in matters of faith publicly known, and in the sequel has passed uncondemned, he is justified henceforth in his position, since no one is deceived thereby, and the responsibility for the toleration of what is prima facie an anomalous state of affairs has been implicitly accepted by the Church. There remains over the question of subscription, with which it appears desirable to deal at somewhat greater length.

VI

The clergy of the Church of England are required in their public ministrations to make use of the Book of Common Prayer, and at the time of their ordination to make certain declarations of assent to the Anglican position in general: and it is commonly urged that they are bound by the strict letter of these 
declarations, as well as by the words of the Church Services, and especially by the Creeds which they daily repeat, to a much more rigorous orthodoxy than the foregoing argument would imply. I propose to examine this contention in detail and to suggest that it cannot, as it stands, be maintained.

The actual declarations made by the clergy are as follows :

(i.) A deacon at his ordination has the question put to him: "Do you unfeignedly believe all the Canonical Scriptures of the Old and New Testaments?" and is directed to make answer, "I do believe them." A priest under like circumstances is asked, "Are you persuaded that the Holy Scriptures contain sufficiently all Doctrine required of necessity for eternal salvation through faith in Jesus Christ? and are you determined out of the said Scriptures to instruct the people committed to your charge, and to teach nothing, as required of necessity to eternal salvation, but that which you shall be persuaded may be concluded and proved by the Scripture?" and replies, "I am so persuaded, and have so determined by God's grace." 
(ii.) A candidate either for the diaconate or for the priesthood declares as follows:

"I, A. B., do solemnly make the following declaration. I assent to the Thirty-Nine Articles of Religion, and to the Book of Common Prayer, and of ordering of Bishops, Priests, and Deacons ; I believe the doctrine of the Church of England, as therein set forth, to be agreeable to the word of God; and in public prayer and administration of the Sacraments, I will use the form in the said book prescribed, and none other, except so far as shall be ordered by lawful authority."

A few words must be said under each of these two heads.

(i.) The question referring to the Holy Scriptures which is addressed to candidates for ordination to the priesthood is apparently intended as a safeguard against unauthorized additions to the Church's faith, and presents no special difficulty from our present point of view. The question addressed to candidates for ordination as deacons is of a rather different nature, and is not uncommonly regarded as involving serious difficulties. There is, in the first place, considerable doubt as to what the 
190 DOGMA, FACT \& EXPERIENCE

question means. It has been maintained that originally the emphasis was intended to be laid upon the word "all" - "Do you unfeignedly believe all the Canonical Scriptures of the Old and New Testaments?" Luther, for example, as is well known, had desired to expunge from the Canon the Epistle of St. James, and the idea that the individual might thus consider himself at liberty, while expressing his belief in the Holy Scriptures, to make his own selection of the books which he was prepared to acknowledge as canonical, the Church of England, according to this view of the matter, repudiated by the expedient of requiring the candidate for Orders to declare his belief in the whole of the accepted Canon.

Apart from this suggestion, it is really not at all easy to see what precisely the words of the question are intended to mean. We are driven to ask what is meant by "believing" a book, or rather a set of books. Is it to be supposed that an affirmative answer to the question implies the belief that all the statements made in the books of Scripture are true? And if so, in what sense? Truth literal or truth spiritual? Truth of history 
or truth of parable? Or must we necessarily choose between them? It has been proposed in recent years to define the sense of the question by the addition to it of the words "as conveying to us the revelation of God, brought to its fullness in Jesus Christ," or to substitute in place of the existing formula the words, "Do you believe in the Holy Scriptures as given by inspiration of God?" For the present the question stands in its unaltered form, and there is no doubt that to the mind of the plain man it is extremely apt to suggest the ideas associated with such phrases as "Biblical infallibility" or " verbal inspiration," and to convey the impression that the clergy are committed to a pre-critical view of the Bible. Nevertheless I think it is fair to say that that is not how the mind of the Church to-day understands it. The recognition, in all authoritative circles, of the legitimacy and the necessity of applying critical methods and interpretations in the study of the sacred Scriptures has become so universal, that the general acceptance of the books of the Old and New Testaments as the classical literature of Christianity and the primary documents of 


\section{DOGMA, FACT \& EXPERIENCE}

the Church's faith must be held to constitute, on the part of the candidate for Holy Orders who answers this question, a sufficient compliance with the animus imponentis; and it is, in fact, pretty generally understood that the clergy are not to be regarded as being necessarily committed to more than this. They have affirmed in general terms an unfeigned belief in the Holy Scriptures; their belief is to be guided in details by their critical study of the truths which the Scriptures convey.

(ii.) The Thirty-nine Articles of Religion at one time carried a much higher degree of authority than they do to-day. Down to the year 1865 a formula of subscription had to be signed in the following terms: "I, A. B., do willingly and from my heart subscribe to the Thirty-nine Articles of Religion and to the three articles in the Thirty-sixth Canon, and to all things therein contained "; and the Articles were regarded as prescribing and as securing within the Church of England something like a rigid uniformity of doctrine. Prefixed to them as they now stand is the document known as His Majesty's Declaration, 
which dates from the time of Charles I., and was inspired by Archbishop Laud. The object of this curious manifesto was to put an end to the controversy which had been raging at the time between Calvinists and Arminians: and the Declaration enjoins upon divines of all schools that "no man shall ... draw the Article aside in any way, but shall submit to it in the plain and full meaning thereof: and shall not put his own sense and comment to be the meaning of the Article, but shall take it in the literal and grammatical sense."

That the Declaration should have proved nugatory is not to be wondered at, since it rests upon the assumption that words have a meaning in themselves, apart from what people mean by them. There is no such thing, properly speaking, as the intrinsic meaning of words, which are at best only the rough symbols of conventional exchange, whereby we endeavour to convey to others, as best we may, a meaning which inheres, not in the words we use, but in our own minds and thoughts. That which we commonly know as the dictionary meaning of a word represents only a kind of average of its value in current 


\section{DOGMA, FACT \& EXPERIENCE}

usage: the actual meaning in any given case is always modified in subtle ways by the context, the emphasis, and the personality of the speaker or writer by whom the word is used. Even those by whom the Articles were originally drawn up in all probability meant different things by them: and of those who, in times past, in successive generations subscribed the Articles, no two persons can have placed upon them a construction which was absolutely and in all particulars identical.

Nevertheless there can be little doubt that the Articles, as glossed by His Majesty's Declaration, exercised a cramping effect on the minds and consciences of the clergy, until the bubble was pricked by the publication in 1841 of Newman's Tract $X C$., in which it was shown not merely that the Articles are ambiguously worded, but that their ambiguity was designed. They represent, in effect, a highly ingenious and partially successful attempt on the part of the Elizabethan Bishops to hold English Christianity together by means of a formula of concord, under cover of which Catholics and Protestants (with the exception of the two irreconcilable minorities of Romanists on the one side and 
extreme Puritans on the other) might both alike be induced to remain within the borders of the English Church. Subsequent historical research has upon the whole upheld Newman's contentions. The effect of the Tract was to destroy once and for all the idea that doctrinal uniformity could be secured by the requirement of subscription to the Articles, and in 1865 the authorities both of the Church and of the legislature recognized the fait accompli. Specific subscription was abolished by the joint action of Convocation and of Parliament, and the present declaration of assent in general terms to the doctrine of the Church of England, as set forth in Articles, Prayer Book, and Ordinal taken together, was substituted. It is evident that a formula so vague and general in its character as the one which is at present in use cannot reasonably be taken to commit those who "assent" to it to anything more than a broadly Anglican position; and it is not in actual practice interpreted to mean more than this. Whether, under the circumstances, the continued requirement of formal assent to the Articles is worth preserving may well be doubted, since the profession of general 
196 DOGMA, FACT \& EXPERIENCE

loyalty to the Church of England and of readiness in public ministration to use the forms prescribed in the Prayer Book provides all that is really needed in the way of security. There is in any case a fairly general agreement at the present time that the clergy are not bound in any strict manner by particular words and phrases of the Articles.

There remains for consideration the question of the Creeds. As compared with the Articles, the Creeds stand upon a completely different footing. The former constitute, when all is said, a purely local document, of which the significance is not likely to be permanent, and of which the origin is to be traced in what may be called a chapter of historical accidents. The latter, on the other hand, are of Catholic provenance and usage; the Church as a whole is deeply, and as many would say irrevocably, committed to them; regarded as documents binding consciences they have a vastly greater weight of authority behind them than can be claimed for any 
other form of words whatever. Considered from the point of view of traditional orthodoxy, a departure from the faith of the Creeds is a serious matter.

But, on the other hand, there is no obligation whatever in respect of them which does not bind the laity in precisely the same manner and degree as it binds the clergy. Cleric and layman are committed equally, and in the same degree, to the Apostles' Creed in virtue of their baptism : layman and cleric alike are to recite the Creed in the daily offices, and may only approach communion through the medium of a liturgy which involves the repetition of the so-called Creed of Nicæa. The document known as the Quicunque Vult is directed to be used in the Church of England on certain days as a substitute for the Apostles' Creed at Matins.

That the Church has a more direct interest in the orthodoxy of the clergy than she has in that of her lay members has been already admitted; but the only tenable basis of distinction rests upon the position of the clergyman as an accredited teacher of the Faith : it cannot be made to rest upon the use of the 
198 DOGMA, FACT \& EXPERIENCE

Creeds in worship, since an obligation which is incumbent upon clergy and laity alike can afford no ground for discrimination between them. No doubt the clergyman leads the worship; but he does so not as Mr. X., an individual of such and such convictions, but as the mouthpiece of the congregation. No doubt, again, it is possible for a layman who is conscious of unorthodoxy, as it is not possible under like circumstances for the officiating clergyman, to adopt the expedient of attending Christian worship without joining personally in the recitation of the Creed; but the Church does not contemplate that he should approach communion without doing so, still less that as a preliminary to communion he should solemnly affirm what is untrue. The contention, therefore, that it is dishonest and dishonourable to recite the Creeds in worship without feeling personally committed to the prima facie meaning of each of the clauses taken separately is one which, if sustained, must carry with it the exclusion from communion, not merely of certain clergy, but also of many laymen who are at present regular and devout communicants. It is probable that there are some 
among the critics of "liberalism" who would not shrink even from so extreme an application of their principles as this would imply. A rigorist view of ecclesiastical discipline undoubtedly involves as rigid an insistence upon credal orthodoxy in the case of lay communicants as in that of the clergy, since both are regarded as equally committed in virtue of their baptism. The authorities of the Church, however, have not in practice manifested any disposition to make too precise an inquisition into the beliefs of communicant laymen, and there is a very general agreement that it is inexpedient at the present time that any such inquisition should be made. Moreover, it does not appear that even those who are most actively desirous that disciplinary action should be taken against certain of the clergy are asking that the alleged offenders should be excommunicated, but only that they should be deprived of their authority to teach. The policy is perfectly intelligible, even to those who for their own part regard it as inexpedient. But it is a policy which cannot be justified unless it may reasonably be maintained that to recite the Creeds in worship as a member 


\section{DOGMA, FACT \& EXPERIENCE}

of the Christian Society, with the intention of expressing a general allegiance to the Christian faith, is not necessarily incompatible with the maintenance of an attitude of reserve in respect of particular clauses of the Creeds. If liberty is to be asserted on behalf of the lay communicant, or of the clergyman who has been deprived of the right to exercise his ministry, it must carry with it a corresponding liberty, so far at least as regards the letter of the Creeds considered as forms of words recited in Church, for the clergyman who has not been so deprived. There is, in fact, upon the simple ground of ethics, and of " the veracity required in all public professions," no basis for discriminating between the Creeds and any other "form of words" corporately sung or said in Christian worship. Any distinction which is drawn must rest upon quite other grounds than that of honesty or dishonesty in the use of words. The Creeds are not, in actual usage, tests for the clergy. They are symbols of the Church's common faith, with which clergy and laity alike desire as worshippers to be identified. 


\section{VIII}

It must not be forgotten that Creeds have a long history behind them, and that in the course of that history they have been used in a variety of different ways. Originally framed as short summaries of tradition for the instruction of candidates for Baptism, they were accepted by the catechumen as the expression in summary form of that faith into which he was baptized. At a later date they underwent in some cases expansion or development with a view to the exclusion of forms of doctrine which had come to be judged inadequate, and the maintenance of which was regarded as a mark of heresy. Thus arose "conciliar" as distinct from "baptismal" creeds, our most familiar example being of course the Creed of Nicæa. Conciliar creedsthat is to say, creeds drawn up and agreed upon, sometimes (as at Nicæa) upon the basis of an existing baptismal creed, by a council summoned to consider disputed forms of doctrine-were undoubtedly meant originally as declarations of orthodoxy, and differed from baptismal creeds in being definitely 
"tests," since they were presented for acceptance to particular Christian teachers who were under suspicion of heresy, and who were required to subscribe to them as an evidence of their soundness in the faith. This use of the Creeds as tests, however, is one which has not survived; for though the Apostles' Creed has been used continuously in its original character as the creed of Baptism in the Western Church, the Nicene Creed-or that which we commonly know as the Nicene Creed ${ }^{1}$ - survives in current usage to-day only in virtue of a custom, which appears to have been introduced somewhere about the beginning of the sixth century, of employing the Creeds not as tests, but as formulæ of worship. The practice arose first in Eastern Christendom; we are told that Peter the Fuller, Monophysite Patriarch of Antioch, ${ }^{2}$ originally introduced the Creed into the Liturgy: the usage spread gradually through-

1 The "Nicene Creed" as it stands at present in the Liturgy is not identical with the original Creed of Nicæa, but appears to be a revision, made in view of the decisions of the Councils of Nicæa and Constantinople, of the local creed of the Church of Jerusalem (Hort, Two Dissertations, II.).

2 A.D. $476-478$. 
out the East and eventually reached the West, the recitation of the "Creed of Constantinople according to the use of the Eastern Churches" being ordered by the third Council of Toledo. ${ }^{1}$ In the ninth century the Western Church introduced also its Baptismal Symbol-the existing "Apostles' Creed"-not indeed into the Liturgy, but into the Hour Services which underlie our present Matins and Evensong.

It is not unfair to point out that this was to use the Creeds in an entirely new way. Hitherto they had been either summaries of tradition to be accepted by catechumens (Baptismal Creeds) or tests of orthodoxy to be subscribed by suspected heretics (Conciliar Creeds). Henceforward they became symbols of corporate worship, expressions rather of loyalty to Christ and His Church than of detailed orthodoxy, doxologies rather than declarations of individual doctrine. To recite the Creeds in Church is undoubtedly to be identified, in a general way, in will and desire, with the faith of Christendom as a whole. It cannot rightly be insisted that of necessity it

1 A.D. 589. See Turner, Use of Creeds and Anathemas in the Early Church. 


\section{DOGMA, FACT \& EXPERIENCE}

implies more than this. The atmosphere of worship is a different atmosphere from that in which heretics are anathematized, or the beliefs of individuals subjected to rigid scrutiny.

\section{IX}

The main contentions of this essay may now be shortly summarized as follows:

(1) The Creeds bind clergy and laity equally and in the same degree.

(2) There is a difference between their use in worship and their original significance either as tests of orthodoxy or as summaries of baptismal tradition.

(3) The use of the Creeds as tests of orthodoxy no longer obtains; a rigorist view of discipline implies that clergy and laity must both alike be held, as a term of communion, to the letter of their baptismal profession, but by practice and common consent the communicant status may be retained in the Church by all such as do not feel compelled definitely to repudiate the faith of their baptism.

(4) It is not necessarily a dishonest proceeding to recite the Creeds in worship with a 
general intention of being identified with the historic faith of Christendom as a whole, even though an attitude of reserve be maintained in respect of particular clauses in the Creeds.

(5) Clerical subscription to Prayer Book, Ordinal, and Articles is required only in general terms, and is susceptible of interpretation in a "liberal" sense.

(6) The profession by the clergy of unfeigned belief in the Holy Scriptures is not interpreted by the present mind of the Church as incompatible with the free application to the said Scriptures of critical methods of study.

(7) There is consequently no point at which, upon the mere ground of the letter of formularies subscribed or recited, those who are commonly known as the "liberal" clergy can be attacked in the name of " common honesty."

On the other hand, however :

(1) The Christian Church is entrusted with a definite, though not very easily definable, Gospel.

(2) She has the same right as any other society to satisfy herself that those who teach 
in her name adequately represent and express her mind.

(3). The teacher's commission cannot be claimed by any individual as a right, and involves the obligation not to teach in the Church's name doctrine of which the Church as a whole disapproves.

If these contentions be granted, the problem of the right adjustment between the rival and legitimate claims of orthodoxy upon the one hand and scholarly freedom upon the other is not thereby solved: but the dispute ceases to be one of ultimate principle and largely resolves itself into a question of immediate ecclesiastical expediency. It may reasonably be suggested that a present toleration of ecclesiastical anomalies is more expedient than any such application of discipline as may present the appearance of a desire to shirk issues. The Church has a duty to the future as well as to the present and the past, and the questions of to-day are often best solved in the light of the experience of to-morrow. The bitterness of dispute would in any case be enormously mitigated if there could be an agreement among the dis- 
putants upon either side to abandon the habit of making aspersions upon each other's honour and impugning each other's personal sincerity. What is desirable, in short, is that the ethical question should be dropped as an uncharitable irrelevance, and the ecclesiastical question shelved on the ground that it is inexpedient at the present time to press it, until the theological question, which is the really important issue, has been faced and considered upon its merits, and until a more general agreement has been reached with regard to it than can be said to exist among Christian scholars and thinkers at the moment.

THE END 


$$
\text { (3) }
$$






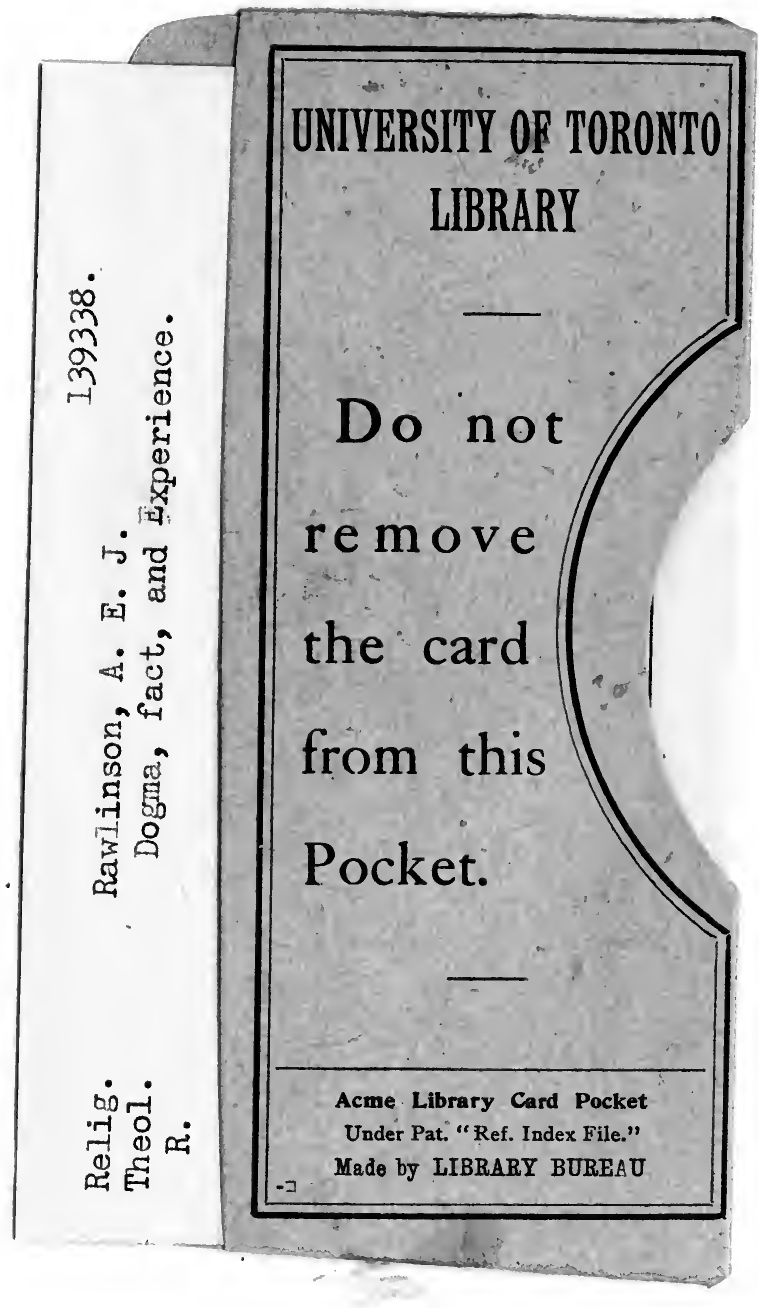


